\title{
75. STRUCTURAL FEATURES IN LEG 128 CORES: RELATIONSHIP WITH THE TECTONIC EVOLUTION OF THE JAPAN SEA ${ }^{1}$
}

\author{
Jacques Charvet, ${ }^{2}$ Kurt Grimm, ${ }^{3}$ John Griffin, ${ }^{4}$ Laurent Jolivet, ${ }^{5}$ André Pouclet, ${ }^{2}$ and Dominique Panis ${ }^{2}$
}

\begin{abstract}
Numerous structural features occur in the Leg 128 cores from the Japan Sea. They include (1) gravity-induced structures such as slump folds, (2) dewatering structures comprising several sets of veins, and (3) larger faults and veins developed in the volcanic basement of the Yamato Basin as well as in the sedimentary rocks of the Oki Ridge and Kita-Yamato Trough. Gravity-induced structures, mainly slumps and associated faults, suggest the existence of paleoslopes and the dominance of gravitational tectonics during the early and middle Miocene, at the Pliocene/Pleistocene boundary, and during the Quaternary. Several types of mud-filled veins having various shapes were observed. These are especially abundant in the middle Miocene siliceous claystones and porcellanites from the Kita-Yamato Trough. They have been interpreted as dewatering conduits that formed preferentially in highly porous, water-saturated diatomaceous muds on a slope, because of episodic loss of sediment strength, collapse of the sediment framework, and consequent fluid migration. The central part of the vein serves once as a fluid conduit, whereas the transition between conduit-controlled and intergranular flow occurs at the branching extremities, with concentration of fines. The likely trigger responsible for the strength loss is seismic activity. Development of these veins, spatially and chronologically linked to small normal microfaults, implies an extensional regime having layer-parallel extension and a local bedding-parallel shear couple, probably the result of gravitational gliding.

The brittle fractures found in Yamato Basin basement Hole 794D cores comprise joints, faults, and veins filled with chlorite-saponite, saponite, and calcite. They suggest a likely transpressive to transtensional regime around the early Miocene/middle Miocene boundary, with a north-northeast-south-southwest compression alternating with a west-northwest-eastsoutheast extension. The faults from Site 799 cores on the Yamato Rise exhibit a prominent early Miocene-middle Miocene extensional environment, a late Miocene-early Pliocene phase of normal and strike-slip faulting, and a final phase that began during the latest Pliocene. Site 798, on the Oki Ridge, reveals faults that recorded a consistent extensional tectonic regime from Pliocene to the Holocene.

These data support the pull-apart kinematic model for early Miocene-middle Miocene time, as regarding the stress regime deduced from the Yamato Basin basement fractures. The recent compression known in the eastern margin of the Japan Sea was not documented by compressive structures at any site. The late Miocene-early Pliocene faulting phase corresponds to a major and general reorganization of the stress distribution in the arc area. Evidence for rapid and main subsidence and synsedimentary extension of the Yamato Basin and Yamato Rise areas between 20 and $15 \mathrm{Ma}$, and the concomitant rotation of southwest Japan, raise the question of links between this opening and the Shimanto Belt collision in southwest Japan, between the arc and the Philippine Sea Plate.
\end{abstract}

\section{INTRODUCTION}

During the summer and early fall of 1989 , two Ocean Drilling Program (ODP) legs (127 and 128) were devoted to drilling of the Japan Sea to clarify the dynamics and timing of its opening in a continental arc setting and the parallel sedimentary-paleoceanographic history (Tamaki, Pisciotto, Allan, et al., 1990; Ingle, Suyehiro, von Breymann, et al., 1990). Leg 127 scientists drilled four sites (Fig. 1); Leg 128 scientists drilled in the northeastern part of the Yamato Basin (Site 794), already drilled during Leg 127, on the Oki Ridge (Site 798) and in the Kita-Yamato Trough (Site 799), central graben of the Yamato Rise (Fig. 1). In other words, during Leg 128 volcanic and sedimentary rocks were recovered from the basement sequence of the Yamato Basin, as well as sediments from the cover of two prominent continent-based structural highs (Fig. 2).

The aims of this study are (1) to review the different structural features encountered in the Leg 128 cores, (2) to interpret their genesis and original environment, and (3) to see how their development meets

\footnotetext{
${ }^{1}$ Tamaki, K., Suyehiro, K., Allan, J., McWilliams, M., et al., 1992 Proceedings of the Ocean Drilling Program, Scientific Results, Vol. 127/128, Pt. 2.

${ }^{2}$ URA CNRS 1366, GDR BRGM-CNRS-Univ. Orléans, Département des Sciences de la Terre, Université d'Orléans, 45067 Orléans Cedex 2, France.

${ }^{3}$ Earth Sciences Board, University of California at Santa Cruz, Santa Cruz, CA 95064 , U.S.A.

${ }_{4}^{4}$ Department of Geology, University of Nebraska, Lincoln, NE 68588-0340, U.S.A.

${ }^{5}$ URA CNRS 1316, Laboratoire de Géologie de IENS, 24 rue Lhomond, 75231 Paris Cedex 5, France.
}

the general tectonic and time constraints of the Japan Sea history. These features comprise three main groups: slump-related structures, dewatering structures, and larger fractures (faults and veins).

\section{GRAVITY-INDUCED STRUCTURES}

Several features related to synsedimentary or late depositional events were encountered at Sites 798 and 799, especially in Holes 798A and 799A, and to a lesser extent in Holes 798C and 799B. These features consist of local irregular nonplanar and nonhorizontal lith-ologic boundaries and slump folding, sometimes accompanied by stratal disruption.

The upper part of the Site 798 sedimentary pile, between 56 and 80 mbsf, shows almost exclusively irregular and nonplanar boundaries, as the slumplike deformations noted are likely due to drilling disturbance (Shipboard Scientific Party, 1990b). Those irregular boundaries have been attributed to gliding of soft sediments before deposition of overlying strata during the middle-upper part of the Quaternary, about 0.5 to $0.7 \mathrm{Ma}$.

Beautiful slump folds were found at Site 799 in Hole 799A, especially in lithologic Unit I, from 10 to 11.2 mbsf and from 40 to 79 mbsf. These developed in the alternations of dark-colored diatomaceous ooze and silty clays (Fig. 2) and are associated with detachment faults and bedding truncation (Pl. 1, Fig. 1). They exhibit disharmonic folding; the geometry of folded layers varies with the lithologies and contrasting physical properties.

The thickness of slumped packets is variable and ranges from a few tens of centimeters to more than $2 \mathrm{~m}$. The slump folding seems 


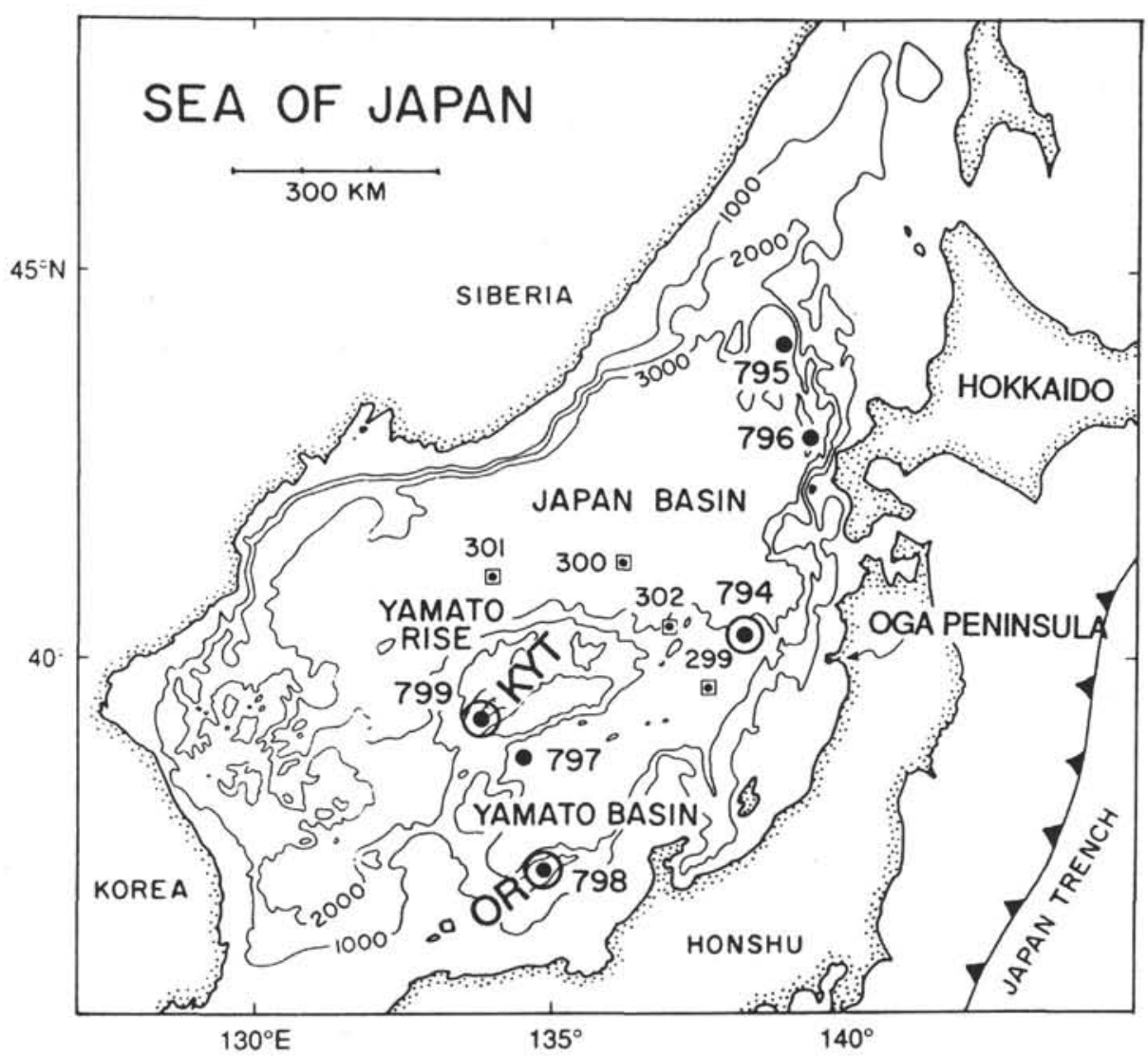

Figure 1. Map of the Japan Sea showing locations of Leg 127 sites (dots), Leg 128 sites (circled dots), and DSDP Leg 31 sites (squares). Bathymetry in meters. KYT: Kita-Yamato Trough; OR: Oki Ridge; O: Oki islands.

to have been facilitated by the banding of sediments, the result of alternation of coarse-grained and clay-rich deposits, probably in two ways. First, the compositional differences between coarse-grained (i.e., porous and permeable layers) and clay-rich (i.e., impermeable and thixotropic layers) together with high sedimentation rates were favorable for the development of elevated pore pressures and consequent sediment failure. Second, the thin layering of contrasting lithologies and rheologies also was favorable for the development of folds during gliding. Some basal normal faults that bound slumped packets can be seen (Shipboard Scientific Party, 1990c).

Evidence of gravity gliding also occurs between 116.5 and $165.0 \mathrm{mbsf}$, around the Quaternary/Pliocene boundary, together with normal faults (see below). Within that interval, bedding dips are the most prominent features, and these range from $30^{\circ}$ to $60^{\circ}$ of apparent dip (Table 1); slump-fold hinges were not identified. Occurrence of a large-scale slumped packet was documented by an overturned sequence covering the first three sections of Core 128799A-17H, from 145.5 to 150.0 mbsf. In Hole 799B, limited additional evidence for slumping, soft sediment gliding, and folding is present at about 500, 635 to 637 , and 888 mbsf (i.e., strata corresponding to early late Miocene and middle Miocene). At approximately 887.7 mbsf in Core 128-799B-47R, a combination of normal faults and reverse faults that post-dates early carbonate diagenesis seems to be the result of layer-parallel extension and some layer-parallel shearing, induced by slope gliding.

In general, between 596.3 and $1084.0 \mathrm{mbsf}$ at the bottom of the hole, bedding dip varies from $0^{\circ}$ to $25^{\circ}$. The scattered attitude of dip values and dip azimuths, deduced from cores oriented from paleomagnetic measurements, precludes a compressive tectonic phase. This conclusion is enhanced by the absence of evidence of folding in the seismic record and of any unconformity or abrupt change in sedimentary facies.

However, most of the bedding dips are oriented toward the northwest (Table 1), which is in agreement with the general inclination of the basement, according to the JNOC 13-4 seismic line (unpubl. data). Tilting caused by block faulting is likely to be responsible for the general dip of these strata. Note that this interval corresponds to the most deformed and faulted part in the seismic record, JNOC 13-4 line, where all the strata below about 600 to 650 mbsf have been affected by a faulting and tilting episode; they correspond to middle and early Miocene.

\section{DEWATERING STRUCTURES}

\section{Macroscopic Description}

Several types of dewatering structures were encountered. At Site 798, these were rare and were mainly developed in the last cores of Hole 798B. They display essentially two aspects. The first type is an array of medium-sized dark veins, about $4 \mathrm{~cm}$ long, mainly parallel, sometimes branching (Pl. 3, Fig. 2). These veins resemble the type $\mathrm{C}$ of Knipe (1986) and are associated with bedding-parallel features and restricted to the siliceous claystones. Their individual dip is at least $65^{\circ}$ to $70^{\circ}$; a small offset of less than $1 \mathrm{~mm}$ of lamination, generally of normal slip, can be seen. The bulk geometry is a band parallel to bedding. These facts argue for an early bedding-parallel extension as the main mechanism responsible (Lundberg and Moore, 1986; Knipe, 1986). The dark filling is composed of in-situ sediment, but those veins were not studied in detail. The second type consists of solitary dark veins, larger in size, up to $8 \mathrm{~cm}$ long having a millimetric thickness (up to $2 \mathrm{~mm}$ ). Typically steeply dipping, they exhibit small 


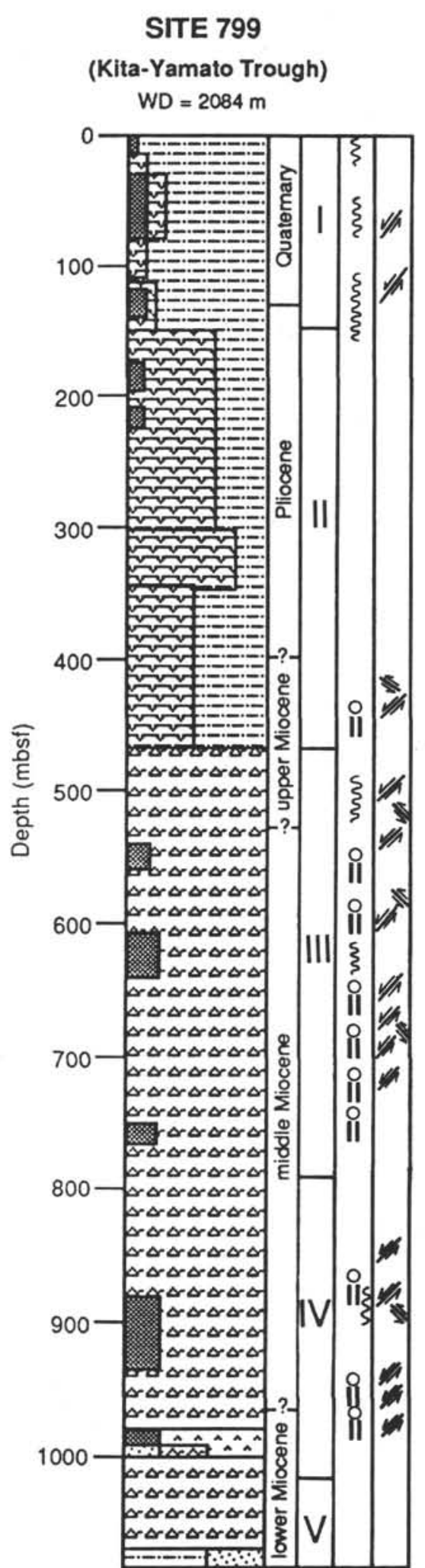

$T D=1084 m$

\section{SITE 794 \\ (Yamato Basin) \\ $W D=2811 \mathrm{~m}$}
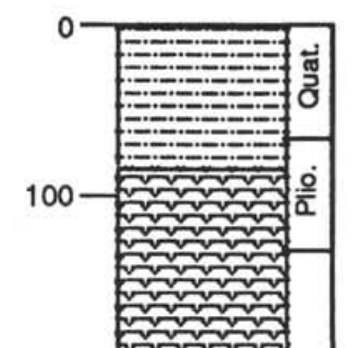

200
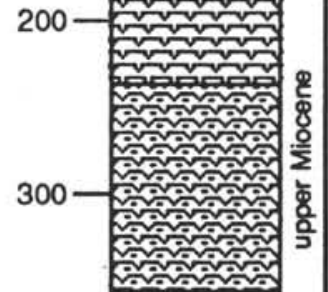

$400-\begin{aligned} & \Delta \Delta \Delta \Delta \Delta \Delta \\ & \Delta \Delta \Delta \Delta \Delta \Delta \\ & \Delta \Delta \Delta \Delta \Delta \Delta A \\ & \Delta \Delta \Delta \Delta \Delta \Delta \Delta \\ & \Delta \Delta \Delta \Delta \Delta \Delta A\end{aligned}$

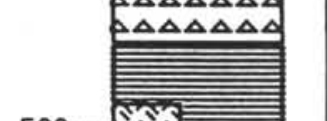

$500-$

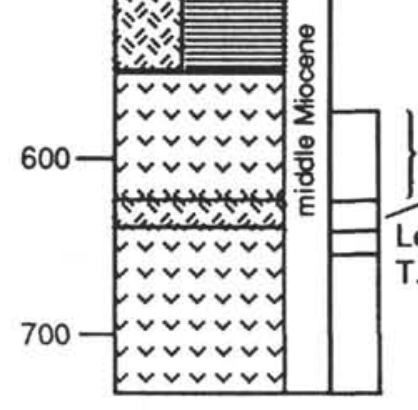

$\operatorname{Leg} 128$

T.D $=734 \mathrm{~m}$

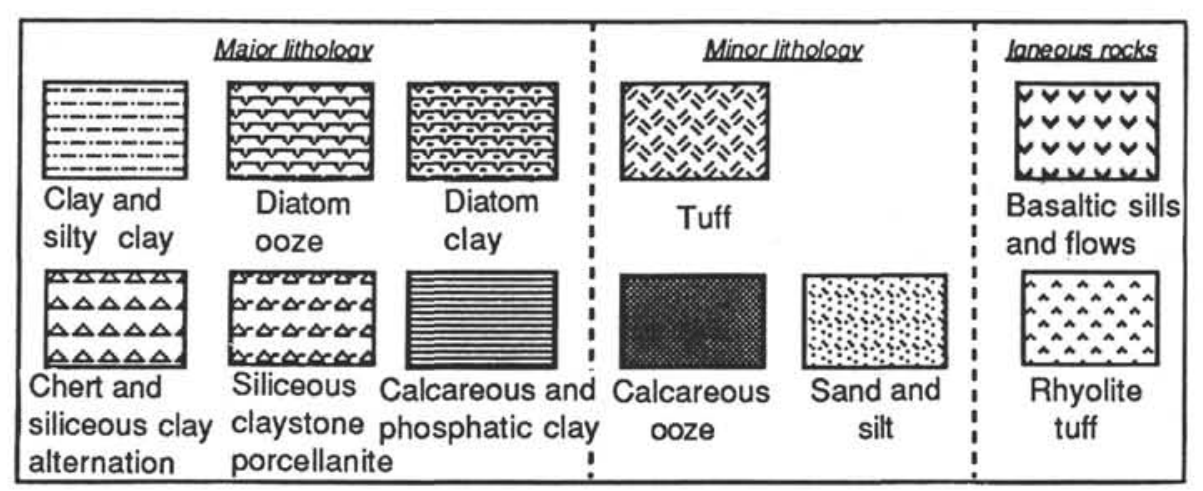

\section{§Slump $\dddot{N}$ Normal fault $\$$ Reverse fault ii Dewatering veins \\ (apparently)}

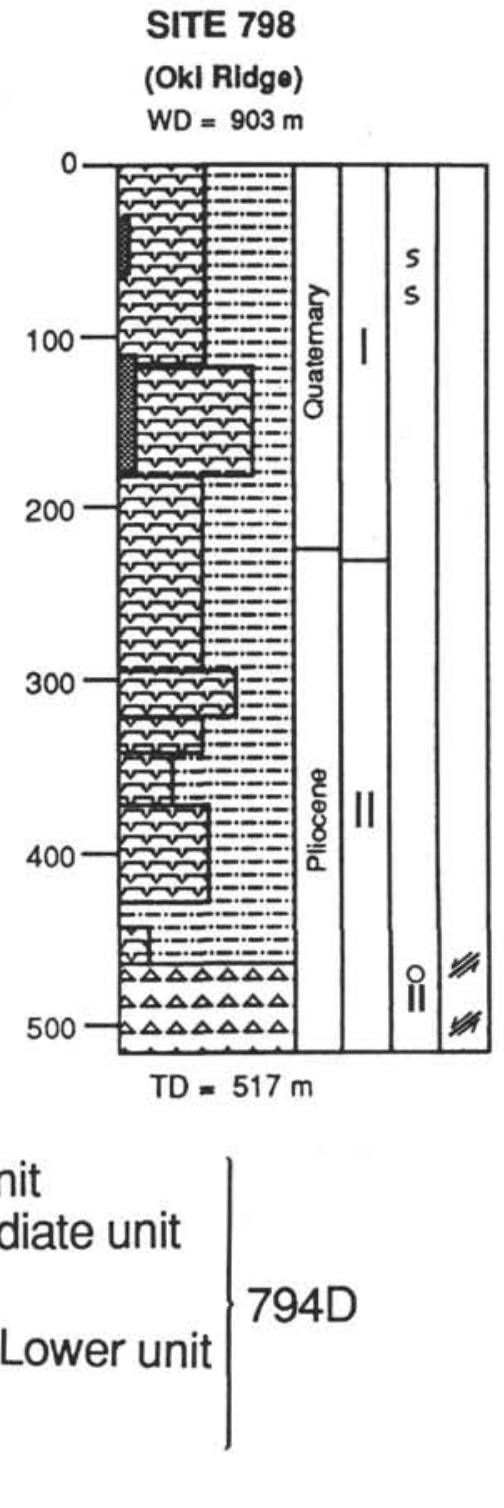

Figure 2. Summary of lithostratigraphic columns for Sites 794, 798, and 799, indicating the main intervals bearing slumps, dewatering structures, and faults. Roman numbers correspond to lithostratigraphic units. In Leg 128, only the bottom part of Site 794 was cored in Hole 794D. 
Table 1. Apparent bedding dips in core-cut sections and apparent azimuth of dip from Hole 799B cores.

\begin{tabular}{|c|c|c|c|}
\hline Core & Section & $\begin{array}{l}\text { Apparent dip } \\
\text { left or right } \\
\left\langle\left({ }^{\circ}\right)\right\rangle\end{array}$ & $\begin{array}{c}\text { Apparent } \\
\text { azimuth } \\
\left({ }^{\circ}\right)\end{array}$ \\
\hline $17 R$ & 2 & $15>$ & N 20 \\
\hline $17 \mathrm{R}$ & 5 & $<10$ & N 250 \\
\hline $17 \mathrm{R}$ & 5 & $<20$ & N 250 \\
\hline $18 \mathrm{R}$ & 6 & $20>$ & N 320 \\
\hline $18 \mathrm{R}$ & 6 & $10>$ & N 320 \\
\hline 2IR & 6 & $<0-10$ & (?) \\
\hline $22 \mathrm{R}$ & 1 & $15>$ & (?) \\
\hline $27 \mathrm{R}$ & 3 & $15>$ & N 330 \\
\hline $27 \mathrm{R}$ & 4 & $10>$ & N 20 \\
\hline $46 \mathrm{R}$ & 2 & $5>$ & N 300 \\
\hline $46 \mathrm{R}$ & 4 & $<20$ & (?) \\
\hline $46 R$ & 4 & $5>$ & (?) \\
\hline $47 R$ & 1 & $<5$ & N 350 \\
\hline $47 R$ & 2 & $30>$ & (?) \\
\hline $47 R$ & 2 & $<60$ & (?) \\
\hline $54 \mathrm{R}$ & 2 & $<10$ & (?) \\
\hline $55 \mathrm{R}$ & 1 & $<12$ & N 350 \\
\hline $56 \mathrm{R}$ & 1 & $<15$ & N 20 \\
\hline $56 \mathrm{R}$ & 2 & $<20$ & N 10 \\
\hline $56 \mathrm{R}$ & 3 & $<22$ & N 350 \\
\hline
\end{tabular}

macroscopic normal offset or no offset at all. Similar to the Nankai Trench hemipelagite "pseudoveins" (Lundberg and Moore, 1986), according to our opinion, these are healed normal faults. This second type of vein is mainly represented between 400 and $470 \mathrm{mbsf}$, within the Pliocene sequence. However, one vein was observed in Hole 798A at the interval 128-798A-15H-3, 47-65 cm, at about $136.4 \mathrm{mbsf}$, in the Quaternary biosiliceous ooze. A different white vein about $30 \mathrm{~cm}$ long was found in the interval at $128-798 \mathrm{~A}-5 \mathrm{H}-1,118-150 \mathrm{~cm}$ (38 mbsf), filled with volcanic ash-derived material (Pl. 1, Fig. 5). The tension gash shape and the difference between the matrix and the vein-filling material argue for a brittle failure that opened a crack into the diatomaceous clay in a shallow environment, under layerparallel extension. This implies a high fluid pressure to support the load of overlying sediments, which is documented by the high fluid content and high porosity measured at that depth (Shipboard Scientific Party, 1990b).

At Site 799, several types of dewatering or water-escape structures were noticed. First, a few examples of flame structures or small-scale mud plumes occur at the boundary between underlying clayey layers and overlying coarse-grained volcanic ash beds near $463 \mathrm{mbsf}$ in Hole 799A and 587 mbsf in Hole 799B. Muddy chimneys intrude the sandy layers and can be traced upward into normal faults.

Second, dewatering veins of various geometries, rare in Hole 799A, are fairly abundant in Hole 799B between 547 and 723 mbsf and about 971 to 973 mbsf. These are especially well developed in the middle Miocene siliceous claystones between 663.8 and 720.1 mbsf from Cores 128-799B-24R to 128-799B-27R, as well as most complicated in shape. There, they are usually strata-bound, limited within zones of $3 \mathrm{~mm}$ to $4 \mathrm{~cm}$ thick, and display various shapes: arrays of suparallel sigmoidal microfractures, with complex dendritic branches at their upper and lower extremities, or anastomosing sets (Pl. 2, Figs. 1, 2; Pl. 3, Figs. 1-3). Up to four orders of dendritic branching can be recognized in some veins.

In some cases, steeply dipping dentritic fractures crosscut older ones, which are more gently dipping and/or more contorted in shape. Even some subhorizontal vein arrays occur; these pre-date the steep ones, as in the Peru margin case (Lindsley-Griffin et al., 1990). The succession of processes is clearly shown in several intervals, the result of the crosscutting relationship between vein structures and associated fabrics. Vein formation post-dates bioturbation (when present), precipitation of authigenic carbonate concretions (Pl. 3, Fig. 3), and some burial compaction. This usually pre-dates some prominent episodes of normal faulting (Pl. 2, Fig. 2). However, some normal faults are parallel to vein networks, and individual veins can abut such faults, which suggests a genetic relationship between the formation of the veins and fault movement. Such was observed, for instance, in the interval at 128-799B-27R-2, 106-118 cm (Shipboard Scientific Party, 1990c, Fig. 69, p. 285), where some microfaults linked with veins exhibit a clear normal offset of a few millimeters (Pl. 3, Fig. 3). Veins having a simpler geometry were observed in other intervals as well. In Hole 799A, in Section 128-799A-50X-1, 59-68 cm, a few dark, rarely branching veins are displayed within the upper Miocene claystone; a small normal offset can be seen along the longest one.

Within the lower to middle Miocene siliceous claystone at 971 to 973 mbsf in Hole 799B, simple, basically branching veins are subperpendicular to bedding and are strata-bound.

\section{Microscopic Constitution}

Thin sections of vein-bearing samples were examined under optical microscope and using SEM techniques. As already observed in many other cases of mud-filled veins (Carson et al., 1982; LindsleyGriffin et al., 1990), the veins are darker in color than the surrounding matrix (Pl. 3, Fig. 2). The material of the vein-fill is similar in composition to matrix sediment; at first glance, it consists mainly of diatomaceous clay, then eventually is slightly silty. However, energy dispersion (ED) scans reveal a slightly higher concentration of iron within some veins. This increase in iron may explain the dark color through the concentration of iron oxides. Microscopic observation indicates that the vein-fill typically is finer-grained than the matrix; moreover, the veins possess a concentration of fines at their margins, which defines a sharp contact, with a distinct textural change (Pl. 4, Fig. 1). In addition, biosiliceous detritus and clay minerals are commonly aligned parallel to subparallel vein walls. However, SEM photographs show two different cases (Pls. 3, 4, 5). The first case, which is rather unusual, shows a clear contrast between vein and matrix, for a mud-filled vein in diatomaceous silt (Pl. 4, Figs. 2, 3, 4). This contrast permits clear recognition of bifurcation or trifurcation at the vein extremities; the latter was observed in only a single instance. The geometry of the margins of the veins, with "fingerlike" extremities, suggests high fluid pressure within the vein and injection of vein sediments and fluid into host sediment during vein formation. In the second case, the vein vs. matrix is difficult to image, and the vein may even appear to be coarser-grained than the sediment in the SEM picture (Pl. 3, Fig. 4; Pl. 5, Figs. 2-5). This has to be explained (see discussion below).

\section{DISCUSSION OF ORIGIN OF VEINS}

Our observations, when compared with previous descriptions (Carson et al., 1982; Cowan, 1982; Ritger, 1985; Lundberg and Moore, 1986; Knipe, 1986; Lindsley-Griffin et al., 1990; Kemp, 1990), allow us to comment on various models of vein formation and to give some conclusions about the tectonic environment of vein structures.

\section{Fluid Flow and Transport of Material}

The enrichment of veins in iron oxides and/or pyrite relative to the surrounding sediments suggests migration of mineralized pore fluids into the veins. In the Peru margin, Lindsley-Griffin et al. (1990) noticed a similar enrichment in authigenic carbonate, iron sulfides, and iron oxides. Knipe (1986) observed an enrichment in pyrite. In our study, calcium enrichment was not constant, whereas a steady increase in iron was found. Mass transfer and fluid flow are not well documented in our samples by streaming or transport of vein-fill. However, slight orientation of diatom remnants (Pl. 5, Fig. 5) and of clay minerals parallel to the walls is consistent with flow, although it 
may result from other mechanisms, such as shearing along the vein (Arthur et al., 1980) or porosity collapse (Knipe, 1986). We did not notice any evidence of shearing and grain breakage (cataclasis) responsible for the finer-grained material at the margin. The presence of very fine material within veins and especially at the margins implies some flushing of material from the matrix, the result of some pore fluid migration toward the vein, accompanied by matrix sieving. As mentioned by Kemp (1990), it is difficult to infer a mechanism for redistribution of fines without any fluid flow.

\section{Problem of Coarse-Grained Material}

As stated above, SEM images seem to document that some parts of veins have concentrated coarse elements: diatom relicts, silt grains, etc. This is a puzzling observation. We think that several explanations are possible. One possibility is the presence of upward-streamed particles that have come from coarser laminae, as evidenced in the Peru margin cores (Kemp, 1990; Lindsley-Griffin et al., 1990); however, such a bed was not identified in our thin sections. Another hypothesis is that the fine particles have been partly washed from the central part of the veins during fluid migration. On the contrary, the fluid-driven mud will concentrate at the branching extremities and partly return to the surrounding sediment by matrix sieving when the transition occurs between conduct-controlled and intergranular flow. This may account for the case of the concentration of slightly aligned diatom remnants (Pl. 5, Fig. 5) in Sample 128-799B-38R-1, 112-115 $\mathrm{cm}$. In addition, back-scattered electron imagery (BSEI) revealed some light-colored rounded grains (PI. 3, Fig. 4) having a higher mean atomic number. This fact, together with the dark and somehow brown color of veins under the microscope, suggests the presence of iron oxides that precipitated from the pore fluids.

\section{Interpretation of Sequence of Phenomena}

We propose the following scenario for the formation of veins as dewatering conduits: (1) deposition of diatomaceous and organic-rich silty mud; (2) burial and strengthening of sediment matrix by diagenetic bonding as a result of organic matter (Hill and Marsters, 1990; Reimers, 1982; Keller, 1983), which permits a high shear strength despite a very high water content; (3) decrease of permeability, lowering hydraulic conductivity (Marsters and Christian, 1990); the result is a sediment having very high porosity, high fluid content, and high shear strength that supports high fluid pressure but is vulnerable to failure in case of loss of strength; (4) initiation of instability (likely by seismic trigger); (5) abrupt loss of sediment strength. At the initiation of abrupt sediment failure, the fluid-saturated sediments experience vertical shortening associated with collapse of the previously stable sediment framework. Simultaneously, the failure of the sediment framework (and consequent reduction in tensile strength) permits the dilatent component of a slope-related, bedding-parallel shear couple to initiate a volume increase (tension gash) in the sediment mass (Fig. 3). As a result of simultaneous vertical collapse and dilatent volume increase, pore fluid migration takes place. Fluid migration is driven by intergranular volume reduction associated with collapse and by a pressure gradient sourced in the low pressure zone at the site of dilatent volume increase. These dilatent voids ("tension gashes") are specific sites where mud-filled veins have formed (Ogawa and Miyata, 1985).

During their migration toward the new and evolving dilatent voids, pore fluids entrain sediment (Fig. 3). As fluids and transported sediments travel along an intergranular flow path, the collapsing mass of sediments acts as a sieve, restricting the migration of coarser grains and permitting the finer grains to pass. As a result, the fluids
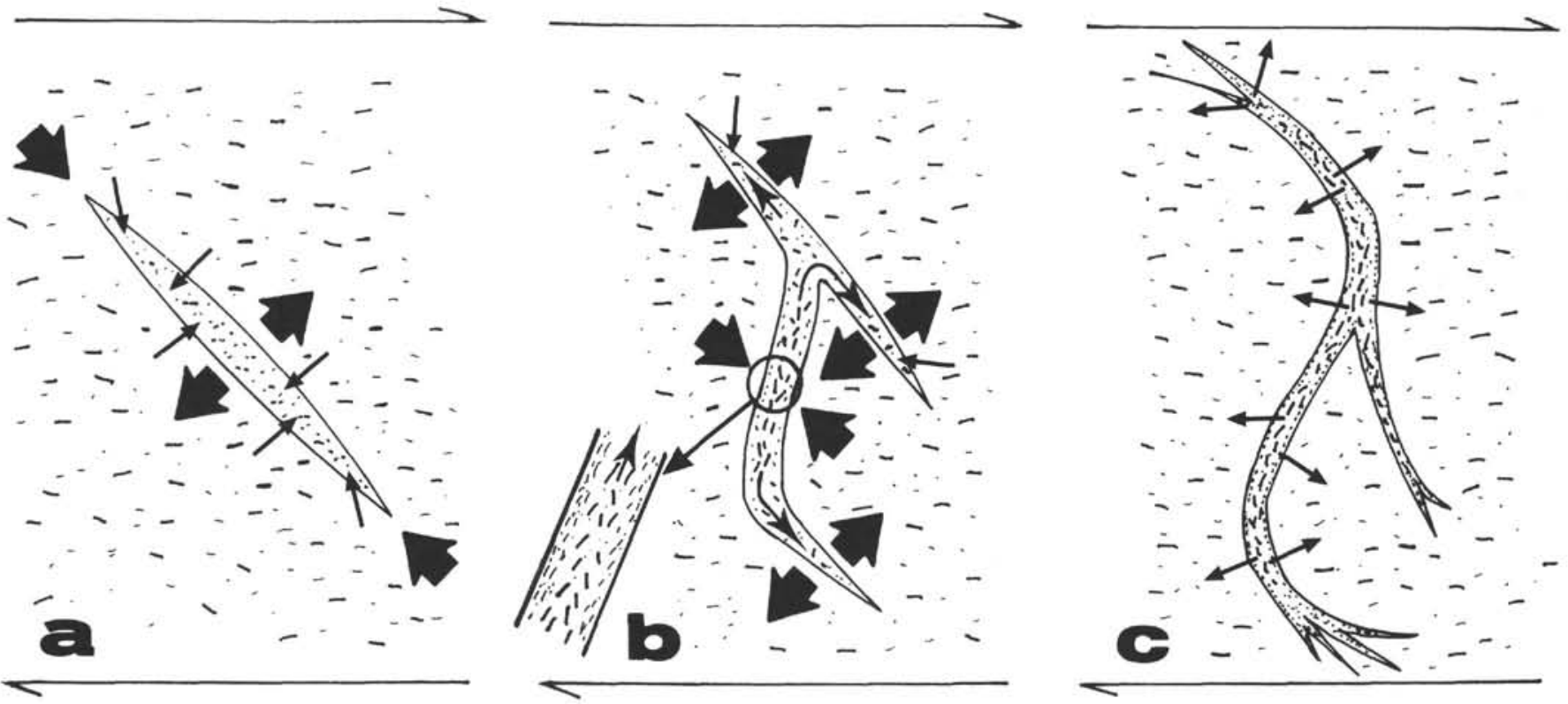

Figure 3. Speculative model of sigmoidal vein development, modified after Knipe (1986) and Brown and Behrmann (1990). A. Initiation of dilatent fracture perpendicular to the incremental direction of extension due to the simple shear couple, migration of fluid, and entrained sediment into the void; the entrained sediment is finer-grained than the matrix due to matrix sieving. B. Growing of tension gash as the simple shear continues and rotation of the early formed central part out of plane of incremental extension, leading to initiation of collapse of this central part and expelling of fluids toward the extremities and into new dilational branches opening perpendicular to incremental extension; flowage differenciation ("Bagnold effect") concentrates the fines at the margins, the coarse-grained particles at the center. C. Collapse stage, fluids and some entrained fines return to the matrix, the last formed bifurcating extremities are filled with fines only, due to the decrease of flow energy. Large arrows indicate direction of incremental compression and extension in the shear zone; small arrows show the migration of fluids and entrained sediment into, within, and out of the vein. 
deliver sediment to the site of vein formation; the mean and modal sizes of these sediments are substantially finer than the immediately adjacent matrix from which they derived. We term this phenomenon matrix sieving.

The ubiquitous presence of vein bifurcations, whereby the broader vein interiors pass outward to progressively finer veinlets at their distal extremities, suggests formation of veins from their interior outward toward the distal extremities (Fig. 3). We interpret that the evolution of the sigmoidal veins themselves is attributable to rotation of vein tips through the vector of maximum tensile stress (Knipe, 1986; Brown and Behrmann, 1990; Grimm, 1990, 1991; Fig. 3). Fluid migration may have favored continuing brittle fracture and continued outward propagation of vein tips.

Once the sediment failure and episode of dilatancy had ended, the formerly dilatent vein interiors would begin to collapse (Knipe, 1986). The fluid and entrained sediment within the newly formed vein interior should experience squeezing from the collapse of vein walls. The consequent volume reduction of vein interiors would drive transitory pore fluid gradients and force pore fluid and entrained fine sediment from the vein interior into vein walls and through to the surrounding sediment (Fig. 3). Once again, the sieving action of the sediment within the large veins would permit only the finest fraction to migrate outward to the marginal walls of the vein. That might explain the narrow halo of still finer component of sediment about the mud-filled vein ( $\mathrm{Pl}$. 4, Fig. 1). Flattening strain associated with the collapse of vein walls may account for the crude to moderately well-developed lineation of biosiliceous detritus and clasts parallel to vein walls (Knipe, 1986).

An alternative or additional possible explanation for the symmetrical distribution of fines at the margins of veins on one hand, and their concentration at the extremities on the other hand, is the "Bagnold effect." This phenomenon is responsible for a differentiated distribution of particles, depending on their size, during flowage in a narrow conduit (Bagnold, 1954; Bhattacharji and Smith, 1964; Bhattacharji and Savic, 1965). During dilatent evolution and then collapse of the veins, the induced fluid and particulate flow is slower near the margins and faster at the center, which might lead to the concentration of coarse-grained particles in the center and of fine-grained ones at the edges. During dying stages, when the branching tips form as a result of a decrease of the strain rate (Knipe, 1986), the flow would be so slow that it could transport only fine particles; thus, the extremities would be filled with fines only. Such a scenario is tentatively represented in Figure 3, modified after Knipe (1986) and Brown and Berhmann (1990), and summarizes the speculative evolution of sigmoidal veins. The Bagnold effect is well known in the field of magmatology for dike emplacement (e.g., Komar, 1972; Barrière, 1976). These speculations are a working hypothesis that needs more data before conclusion.

\section{Timing of Vein Development}

Occurrence of veins at shallow depths suggests that they can form very early. This is shown also by the fact that they are cut by synsedimentary microfaults (Pl. 2, Fig. 2). However, they post-date some diagenetic processes, such as formation of carbonate concretions (Pl. 3, Fig. 3), and some compaction. Nevertheless, some of the normal faults, which post-date the veins, have their offset partly accommodated by differential compaction (Shipboard Scientific Party, 1990c, Fig. 31, p. 269; Pl. 1, Fig. 4). This supports the idea of a dewatering process during early fracturing, as stated in most previous studies (Arthur et al., 1980; Carson et al., 1982; Cowan, 1982; Lundberg and Moore, 1986; Helm and Vollbrecht, 1985; Knipe, 1986; Lindsley-Griffin et al., 1990; Kemp, 1990), rather than a fracture cleavage affecting lithified sediments, as argued by Ogawa and Miyata (1985) for the Middle America Trench slope sediments, off Guatemala.

\section{Tectonic and Sedimentary Setting}

Most of the veins so far reported from offshore sites occurred in the tectonically active forearc area of convergent margins, especially on the trench inner slopes (Lundberg and Moore, 1986; LindsleyGriffin et al., 1990; Kemp, 1990). Exceptions are the veins reported in the Nankai Trough at DSDP Site 582 and at ODP Site 672 (Leg 110), far from highly deformed sediments of the Barbados forearc (Lundberg and Karig, 1986; Shipboard Scientific Party, 1988). Onshore examples are provided by the Miocene Pisco Formation of Peru (Lindsley-Griffin et al., 1990), the Miocene Monterey Formation of California (Garrison et al., 1981; Grimm, 1990), and the Neogene Miura Group of Central Japan (Ogawa, 1980). The structures reported from various convergent margins and from onshore localities, especially for the Monterey Formation and the Pisco Formation, are similar to the ones noticed in Peru margin sediments (Lindsley-Griffin et al., 1990; Grimm, 1990) and to the structures found in ODP Sites 798 and 799. Similar development may be inferred for those structures, which implies that the forearc location is not a prerequisite condition, although the absence of any report of vein structures from passive margins has been emphasized (Lundberg and Moore, 1986). Two points should be addressed: links with normal faulting and slope gliding and mass wasting, respectively.

The common and consistent co-occurrence of normal microfaults with mud-filled veins, as stated above and reported from the Monterey Formation (Grimm, 1990), suggests that extension and dewatering are two synergetic processes, linked in space and time. Then, an extensional regime during vein formation seems to be clear; in Sites 799 and 798 , this regime persisted after veining, as documented by the healed normal faults offsetting the veins. More typically, brittle behavior occurred after some lithification due to dewatering through veins. Some gradation is seen between dewatering veins and normal microfaults.

The en échelon pattern and the sigmoidal shape of veins, however, argue for a bedding-parallel shear couple. Because this subhorizontal simple shear cannot be due to a compressional regime, the best explanation may be that it was driven by gravitational sliding on paleoslopes. This conclusion is enhanced by the presence of slump folds and gravity gliding features within the same units (see above, and Shipboard Scientific Party, 1990b, 1990c). A similar explanation was proposed for the Peru margin sediments (Lindsley-Griffin et al., 1990) and the Miocene Monterey Formation (Grimm, 1990, 1991).

Abundance of veins is clearly linked to lithology. They are significantly best developed in diatomaceous muds, rather organic-rich (i.e., in sediments having a high porosity, a high fluid content, and, due to rapid burial, a high pore fluid pressure, which they support owing to an unusually high shear strength [Reimers, 1982; Keller, 1983; Hill and Marsters, 1990]). These sediments have a high sensitivity or ratio of natural to disturbed shear strength (Keller, 1983). When they are disturbed, the framework collapses, and the result can be fluidization of sediment and consequent fluid escape. Then, the question arises of the trigger. Lindsley-Griffin et al. (1990) advocated the collapse of diatom frustules. However, the afore-mentioned considerations indicate that an external mechanism breaking the strength of sediments is likely. The same authors also invoked loading due to slumping. However, the slumps are not always closely associated to vein-bearing levels. We would like to favor a more general mechanism, such as seismic activity, efficient through additional horizontal ground acceleration caused by earthquakes, which can also explain the slope instabilities (Holler, 1986), i.e., slumping and gliding, even for gentle slope angles. Such an explanation is consistent with the correlation 
between intensity of veining and evidence of normal faulting from seismic profiles at the considered locations, in the case of Peru margin (Kemp, 1990). This also works for ODP Sites 798 and 799, which show strong normal faulting in seismic profiles, as well as in cores.

In summary, veins developed preferentially in highly porous, fluid over-pressured diatomaceous muds, the result of episodic loss of sediment shear strength that permitted fluid escape. These veins served only once, as a fluid conduit. The likely trigger is the seismic activity linked to normal faulting in an extensional regime.

\section{BRITTLE STRUCTURES}

Interesting sets of fractures (microfaults, joints, filled veins) have been observed in cores from Leg 128 sites (Shipboard Scientific Party, 1990a, 1990b, 1990c). We present the structural features from the Yamato Basin basement (Site 794) and from the Oki Ridge and Kita-Yamato Trough (Sites 798 and 799) separately.

\section{Structural Features from the Yamato Basin Basement (Hole 794D)}

As reported in the Initial Reports volume of Leg 128 (Shipboard Scientific Party, 1990a), fractures observed in Hole 794D cores differ in their geometric attitude, width of alteration halo, and presence or absence and nature of filling material. The opened fractures devoid of any trace of alteration on the walls, likely induced by drilling disturbance, were, of course, not measured. The attitudes of planes were determined in three dimensions on the pieces of cores, assuming that the core axis was vertical. The different fractures encountered are summarized in Table 2. From shore-based studies (Proust et al., this volume), we can say now that the filling material, as a result of hydrothermal alteration, is the following in chronologic order: mixedlayered chlorite-saponite clays, saponite, and calcite, corresponding to decreasing temperature. Pyrite crystals are sometimes present and are associated with chlorite-saponite filling. Their lead isotope compositions are similar to the basalt ones and show a common origin of fluids. The study of the clay and carbonate filling (including isotopic data) and the arrangement of saponite with respect to chlorite-saponite suggest that the mineralizing fluids were a mixture of seawater and fluids that came from the host rock. The filling process is a short event at the geological scale; thus, the filling deposits of upper and lower units are likely of different ages, because the lower magmatic unit is about 3 to 4 m.y. younger than the upper one (Pouclet et al., this volume). Perhaps, several generations of calcite existed, but this had not been clearly determined by geochemical study until now.

Regarding the geometry, the attitude allows at least two basic types to be distinguished: gently dipping and steeply dipping; each group presents some likely conjugate systems (Shipboard Scientific Party, 1990a). Unfortunately, only a few fractures are oriented from paleomagnetic measurements in cores. In Figure 4, we summarize the attitude of oriented fractures; they correspond to features observed within the lower unit. Clearly, the dip azimuths of gently dipping ones cluster into the northeast and southwest quadrants. Those fractures are systematically filled with chlorite-saponite and/or calcite and therefore are now appearing as veins. Moreover, similar ones are arranged in places in sets that show a symmetry with respect to the horizontal; they are assumed to be conjugate, for instance at 666.7 , 664.3, and 666.6 mbsf (Shipboard Scientific Party, 1990a). Although those convincing conjugate sets are not oriented by paleomagnetic measurements, by referring to the attitude of the low-angle veins contained in the oriented parts, we may assume that northeast and southwest dips are likely. Anyway, the presence of flat-lying to gently dipping veins, together with the vertical elongation of calcite fibers within horizontal veins, strongly suggests a stress regime having a horizontal maximum main stress at the time of their initiation and filling. Considering the dip azimuths, a north-northeast to southsouthwest compression was the likely tectonic regime. In detail, some crosscutting relationships, such as a small subhorizontal vein filled with chlorite-saponite, crosscut by a larger one dipping at about $60^{\circ}$, at interval $128-794 \mathrm{D}-14 \mathrm{R}-2$, Piece $2(45-56 \mathrm{~cm})$, indicate that the opening of some flat-lying veins occurred earlier than the genesis of some normal shear joint-type fractures. On the contrary, in the same unit, some subhorizontal veins have been filled only with fibrous calcite, as at interval 128-794-D-12-R-3 at 42-48 cm (Shipboard Scientific Party, 1990a, Fig. 18, p. 90). These veins indicate a vertical extensional movement, clearly shown by the fibrous texture of calcite, during a late stage of fracture filling.

The oriented steeply dipping fractures, which include some conjugate sets of normal shear joints (Shipboard Scientific Party, 1990a, Fig. 20A) have a general north-northeast-south-southwest trending direction (Fig. 4). Together with some other veinlets or veins having a similar attitude, they suggest that a west-northwest to east-southeast extension phase was responsible for their initiation. They are present in the same unit as the flat-lying veins and also are filled with calcite or chlorite-saponite and calcite.

All these data lead to a consideration of a permutation between sigma 1 , sigma 2 , and sigma 3 during the early history of the relevant fractures, synchronous with the hydrothermal alteration and fracture filling, without major changes in the main stress directions: northnortheast-south-southwest, west-northwest-east-southeast, and vertical. This kind of permutation is common in every basin opening history: Gulf of California, west-European, and west-Anatolian grabens, Basins and Ranges, Gulf of Suez (Angelier et al., 1983; Bergerat, 1989). Sigma 1 trending north-northeast-south-southwest and sigma 3 vertical led to the gently dipping fractures system; sigma 1 vertical and sigma 2 trending north-northeast-south-southwest led to the normal shear joint system. In any case, the west-northwest-eastsoutheast direction remained that of the minimum horizontal stress and the north-northeast-south-southwest one that of the maximum horizontal stress. In other words, transition from compression to extension regimes depended on whether the north-northeast-southsouthwest trending main stress exceeded the lithostatic pressure.

More recent faults, post-dating the vein-filling history, are represented by slickensided slip planes that crosscut these veins. They are present in both upper and lower units, for instance at intervals 128-794D-5R-1, 20-23 cm; 128-794D-8R-1, 89-93 cm; 128-794D$16 \mathrm{R}-1,32-35$ and $45-48 \mathrm{~cm}$. Where their dip could be measured (Table 2), it ranges between $70^{\circ}$ and $80^{\circ}$. In general, the slickenlines have a steep pitch: $70^{\circ}$ to $75^{\circ}$, with a down-dip movement; but interestingly, the slickensided fault surface present at interval 128$794 \mathrm{D}-16 \mathrm{R}-1,45-48 \mathrm{~cm}$, shows a pitch of $40^{\circ}$; this fault is a normal dextral strike-slip fault; the others are normal faults. None have been oriented. Regarding the age of formation, one can only say that they are younger than $16 \mathrm{Ma}$.

In summary, the fractures present in Hole 794D record (1) a stress regime in which north-northeast compression and west-northwest extension alternated around the late early Miocene/middle Miocene boundary; (2) a later extensional or transtensional regime. This conclusion about a northeast compression meets the estimated in-situ stress field from the basaltic rock core samples of Hole 794C (Tamaki and Yamamoto, this volume). It fits with the principal stress directions deduced from onshore observations for early Miocene time (Jolivet et al., 1991; Jolivet and Tamaki, this volume).

\section{Faults from Site 798 and 799 Cores}

Besides the small-scale normal microfaults linked to dewatering veins, a few healed fractures that have been interpreted as normal 
Table 2. Reported fractures: joints, faults, and veinlets $(<1 \mathrm{~mm})$, veins $(<1 \mathrm{~mm})$ from Hole 794D.

\begin{tabular}{|c|c|c|c|c|c|c|}
\hline Core & Section & $\begin{array}{c}\text { Interval } \\
(\mathrm{cm})\end{array}$ & Dip angle & $\begin{array}{c}\text { Azimuth of dip } \\
\text { (if known) } \\
\left({ }^{\circ}\right)\end{array}$ & Nature $^{a}$ & $\begin{array}{c}\text { Pitch of } \\
\text { slickensides, } \\
\text { vein thickness }\end{array}$ \\
\hline $4 \mathrm{R}$ & 1 & $20-35$ & 58 & & Joint & \\
\hline $5 R$ & $i$ & $20-23$ & 75 & & Fault & $75^{\circ}(\mathrm{N})$ \\
\hline $8 \mathrm{R}$ & 1 & $89-93$ & 80 & & Vein and fault & $75^{\circ}(\mathrm{N})$ \\
\hline IOR & 1 & $12-14$ & 40 & $224(?)$ & Fault & $80^{\circ} \mathrm{SE}(\mathrm{R})$ \\
\hline $10 R$ & 1 & $34-36$ & 30 & $030(?)$ & Fault & $90^{\circ}(\mathrm{R})$ \\
\hline $10 \mathrm{R}$ & 1 & $34-36$ & 75 & & Fault & $75^{\circ} \mathrm{SW}$ \\
\hline $11 \mathrm{R}$ & 2 & $77-94$ & 90 & & T.G. vein $(\mathrm{Ca})$ & \\
\hline $12 \mathrm{R}$ & 1 & $85-111$ & 50 & & Joint & \\
\hline $12 \mathrm{R}$ & 1 & $85-111$ & 45 & & Joint & \\
\hline $12 \mathrm{R}$ & 1 & $85-111$ & 75 & & Joint & \\
\hline $12 \mathrm{R}$ & 1 & $85-111$ & 55 & & Joint & \\
\hline $12 \mathrm{R}$ & 1 & $85-111$ & 56 & & Joint & \\
\hline $12 \mathrm{R}$ & 1 & $85-111$ & 25 & & Joint & \\
\hline $12 \mathrm{R}$ & 1 & $111-123$ & 40 & & Veinlet $(\mathrm{Ca})$ & \\
\hline $12 \mathrm{R}$ & $i$ & $111-123$ & 46 & & Veinlet $(\mathrm{Ca})$ & \\
\hline $12 \mathrm{R}$ & 1 & $123-133$ & 63 & & Joint & \\
\hline $12 \mathrm{R}$ & 1 & $131-148$ & 67 & & Vein $(\mathrm{Sa}-\mathrm{Ca})$ & $5 \mathrm{~mm}$ \\
\hline $12 \mathrm{R}$ & 2 & $48-53$ & 48 & & Vein $(\mathrm{Sa}-\mathrm{Ca})$ & $15 \mathrm{~mm}$ \\
\hline $12 R$ & 2 & $68-75$ & 85 & & Vein (Sa) & $9 \mathrm{~mm}$ \\
\hline $12 \mathrm{R}$ & 2 & $85-86$ & & & Vein (Sa) & $9 \mathrm{~mm}$ \\
\hline $12 \mathrm{R}$ & 2 & $94-96$ & & & Vein $(\mathrm{Sa}-\mathrm{Ca})$ & $4 \mathrm{~mm}$ \\
\hline $12 R$ & 2 & $101-104$ & & & Vein (Sa) & $6 \mathrm{~mm}$ \\
\hline $12 R$ & 2 & $109-112$ & & & Vein (Sa) & $5 \mathrm{~mm}$ \\
\hline $12 \mathrm{R}$ & 2 & $118-128$ & 25 & 025. & Fault & 90 \\
\hline $12 R$ & 2 & $118-128$ & 70 & 011. & Veinlet (Sa) & \\
\hline $12 \mathrm{R}$ & 3 & $0-10$ & 28 & & Veinlet (Sa) & \\
\hline $12 \mathrm{R}$ & 3 & $0-10$ & 35 & & Veinlet (Sa) & \\
\hline $12 R$ & 3 & $11-30$ & 58 & 100 & S.J.V. (Ca) & \\
\hline $12 R$ & 3 & $11-30$ & 55 & 302 & S.J.V. (Ca) & \\
\hline $12 \mathrm{R}$ & 3 & 45 & 10 & & Vein $(\mathrm{Ca})$ & $3 \mathrm{~mm}$ \\
\hline $12 \mathrm{R}$ & 3 & $45-55$ & 90 & & Vein $(\mathrm{Sa}-\mathrm{Py}-\mathrm{Ca})$ & $3 \mathrm{~mm}$ \\
\hline $12 \mathrm{R}$ & 3 & $63-80$ & 30 & & Veinlet & \\
\hline $12 \mathrm{R}$ & 3 & $63-80$ & 65 & & Veinlet & \\
\hline $12 \mathrm{R}$ & 3 & $84-115$ & 30 & & Joint & \\
\hline $12 \mathrm{R}$ & 3 & $84-115$ & 30 & & Joint & \\
\hline $12 \mathrm{R}$ & 3 & $84-115$ & 29 & & Joint & \\
\hline $12 \mathrm{R}$ & 3 & $84-115$ & 38 & & Joint & \\
\hline $12 \mathrm{R}$ & 3 & $84-115$ & 65 & & Joint & \\
\hline $13 R$ & 1 & $25-50$ & 90 & & Joint & \\
\hline $13 R$ & 1 & $25-50$ & 66 & & Vein $(\mathrm{Sa}-\mathrm{Ca})$ & $10 \mathrm{~mm}$ \\
\hline $13 R$ & $i$ & $66-70$ & -15 & Conjugate & Vein $(\mathrm{Sa}-\mathrm{Ca})$ & $\sim 9 \mathrm{~mm}$ \\
\hline $13 R$ & 1 & $66-70$ & $\sim 15$ & & Vein $(\mathrm{Sa}-\mathrm{Ca})$ & $\sim 8 \mathrm{~mm}$ \\
\hline $13 R$ & 1 & $135-147$ & 11 & & Vein $(\mathrm{Sa}-\mathrm{Ca})$ & $-10 \mathrm{~mm}$ \\
\hline $13 R$ & 2 & $27-57$ & 16 & & Vein $(\mathrm{Sa}-\mathrm{Ca})$ & \\
\hline $13 R$ & 2 & $27-57$ & 70 & & Veinlet & \\
\hline
\end{tabular}

faults are present in Hole $798 \mathrm{~B}$ at about 460 to $465 \mathrm{mbsf}$ in the Pliocene siliceous claystones and claystones. No evidence of compression was noticed (Shipboard Scientific Party, 1990b).

More interesting are the faults present at Site 799, especially in Hole 799B. One can distinguish four main groups.

The first group is represented by numerous healed normal faults, sometimes clearly associated with vein sets, displayed from 519 to 890 mbsf (i.e., essentially within the middle Miocene sediments). These show small offsets of barely $1 \mathrm{~mm}$ up to $2 \mathrm{~cm}$ and have a shallow dip of $30^{\circ}$ or less. Contrary to the sigmoidal dewatering veins, they preferentially affect the silt and carbonate layers and die out in the clayey beds (Pl. 2, Fig. 3). Some display the geometry of curviplanar listric faults. They are locally grouped in an en-échelon set and cut the affected layers in a series of tilted microblocks. These faults reflect a layer-parallel extension that occurred very early while the fluid content was still high, as indicated by their links with the veins and their low dip angle, which suggest a ductile behavior of the silty beds. Thus, these synsedimentary faults are subcontemporaneous with deposition and reveal the marked general extensional regime that prevailed during middle to early late Miocene.

The second group is composed of healed normal faults of greater size than those in the first group that have a steeper dip angle $\left(50^{\circ}-60^{\circ}\right.$ on average) and offsets ranging from 1 to $5 \mathrm{~cm}$ (Pl. 2, Fig. 2). Some conjugate sets are present and delimit small grabens. Some faulted blocks exhibit a slight tilt $\left(10^{\circ}-15^{\circ}\right)$ (PI. 1, Fig. 4). When opened or broken by drilling or handling, these faults exhibit slickensided surfaces. They also occur in the middle Miocene siliceous claystones and porcellanites from 550 to $890 \mathrm{mbsf}$. While post-dating the first group of faults, the second group is probably not much younger, because some differential compaction of clayey beds may have accommodated the offset (Shipboard Scientific Party, 1990c, Fig. 31, p. 269; Pl. 1, Fig. 4).

The third group of faults comprises open, sharp slickensided faults (Pl. 2, Fig. 1), steeply dipping $\left(60^{\circ}-80^{\circ}\right)$. These occur from 465 to $878 \mathrm{mbsf}$, in sediments deposited during middle to late Miocene time. The real dip of these fault planes could be measured and the dip azimuth oriented, in most cases, from paleomagnetic measurements. The different attitudes are summarized in Figure 5. The pitch angle of slickenlines is generally high $\left(70^{\circ}-90^{\circ}\right)$, but in some cases is moderate to low $\left(50^{\circ}-30^{\circ}\right)$, which indicates a significant strike-slip component of fault motion. All the slickenslides have been interpreted as indicating a normal slip. As shown in Figure 5, the fault planes are scattered and thus difficult to interpret. They cluster roughly into two sets: one around the northwest trend and the other around the northeast trend. The vertical distribution is apparently the same; thus, they are synchronous. Tentatively, we can speculate that the stress system 
Table 2 (continued).

\begin{tabular}{|c|c|c|c|c|c|c|}
\hline Core & Section & $\begin{array}{c}\text { Interval } \\
(\mathrm{cm})\end{array}$ & Dip angle & $\begin{array}{l}\text { Azimuth of dip } \\
\text { (if known) } \\
\left({ }^{\circ}\right)\end{array}$ & Nature $^{a}$ & $\begin{array}{c}\text { Pitch of } \\
\text { slickensides, } \\
\text { vein thickness }\end{array}$ \\
\hline 13R & 2 & $27-57$ & 24 & & $\operatorname{Vein}(\mathrm{Sa}-\mathrm{Ca})$ & $20 \mathrm{~mm}$ \\
\hline $13 \mathrm{R}$ & 2 & $27-57$ & 27 & & Vein $(\mathrm{Sa}-\mathrm{Ca})$ & $10 \mathrm{~mm}$ \\
\hline $13 \mathrm{R}$ & 2 & $27-57$ & 86 & & Veinlet & \\
\hline $13 \mathrm{R}$ & 2 & $60-68$ & 22 & & Vein $(\mathrm{Sa}-\mathrm{Ca})$ & $>5 \mathrm{~mm}$ \\
\hline $13 R$ & 2 & $92-98$ & 75 & & Joint & \\
\hline $13 \mathrm{R}$ & 2 & $92-98$ & 15 & & Joint & \\
\hline $13 R$ & 2 & $140-147$ & 42 & & Fault & $-90^{\circ}$ \\
\hline $13 R$ & 2 & $140-147$ & 35 & & Veinlet (Ca) & \\
\hline $14 \mathrm{R}$ & 1 & $0-20$ & 75 & & Joint & \\
\hline $14 \mathrm{R}$ & 1 & $0-20$ & 52 & & Veinlet & \\
\hline $14 \mathrm{R}$ & 1 & $20-28$ & 70 & & Vein and fault & $70^{\circ}(\mathrm{N})$ \\
\hline $14 \mathrm{R}$ & 1 & $30-37$ & 40 & & Vein (Sa) & \\
\hline $14 \mathrm{R}$ & $i$ & $45-64$ & 80 & & Joint & \\
\hline $14 \mathrm{R}$ & 1 & $95-104$ & 18 & $164(?)$ & Joint & \\
\hline $14 \mathrm{R}$ & 1 & $95-104$ & 50 & $301(?)$ & Veinlet & \\
\hline $14 \mathrm{R}$ & 1 & $95-104$ & 72 & $324(?)$ & Fault & \\
\hline $14 \mathrm{R}$ & 2 & $22-28$ & 35 & & Vein (Sa) & \\
\hline $14 \mathrm{R}$ & 2 & $45-46$ & 60 & & Vein 2 (Sa) & $15 \mathrm{~mm}$ ) \\
\hline $14 \mathrm{R}$ & 2 & $45-46$ & 15 & & Vein 1 (Sa ?) & $4 \mathrm{~mm}\}$ \\
\hline $14 \mathrm{R}$ & 2 & $64-80$ & 22 & 256 & Veinlet & \\
\hline $14 \mathrm{R}$ & 2 & $64-80$ & 26 & 022. & Veinlet & \\
\hline $14 \mathrm{R}$ & 2 & $64-80$ & 63 & 099. & Joint & \\
\hline $14 \mathrm{R}$ & 2 & $82-91$ & 40 & & Vein (Sa-Ca-Py) & $\sim 10 \mathrm{~mm}$ \\
\hline $14 \mathrm{R}$ & 2 & $82-91$ & 50 & & Vein $(\mathrm{Sa})$ & \\
\hline $14 \mathrm{R}$ & 2 & $102-111$ & 75 & & Vein $(\mathrm{Sa}-\mathrm{Ca})$ & $5 \mathrm{~mm}$ \\
\hline $14 \mathrm{R}$ & 2 & $102-111$ & 55 & & Vein $(\mathrm{Sa}-\mathrm{Ca})$ & $10 \mathrm{~mm}$ \\
\hline $14 \mathrm{R}$ & 2 & $102-111$ & 50 & & Joint & \\
\hline $14 \mathrm{R}$ & 2 & $102-111$ & 48 & & Joint & \\
\hline $15 \mathrm{R}$ & 1 & $8-16$ & 45 & & Joint & \\
\hline $15 \mathrm{R}$ & $i$ & $8-16$ & 40 & & Vein and fault (Sa) & $30^{\circ}$ \\
\hline $15 R$ & 1 & $32-45$ & 60 & & Fault & $80+20^{\circ}(\mathrm{N})$ \\
\hline $16 \mathrm{R}$ & 1 & $32-43$ & 58 & & Vein (Sa) & $5 \mathrm{~mm}$ \\
\hline $16 \mathrm{R}$ & 1 & $32-43$ & $60-65$ & & Fault & $70^{\circ}(\mathrm{N})$ \\
\hline $16 \mathrm{R}$ & $i$ & $86-95$ & 30 & & Vein $(\mathrm{Sa}-\mathrm{Py})$ & $1-10 \mathrm{~mm}$ \\
\hline $16 \mathrm{R}$ & 1 & $109-118$ & 28 & 004. & Veinlet & \\
\hline $16 \mathrm{R}$ & 1 & $109-118$ & 76 & 256 & Vein (Sa) & $>3 \mathrm{~mm}$ \\
\hline $16 \mathrm{R}$ & 1 & $65-72$ & 50 & & Veinlet & \\
\hline $16 \mathrm{R}$ & 1 & $65-72$ & 60 & & Veinlet & \\
\hline $17 \mathrm{R}$ & I & $25-35$ & 70 & & Joint-veinlet & \\
\hline $17 \mathrm{R}$ & 1 & $35-46$ & 46 & 012. & Vein (Sa) & $7 \mathrm{~mm}$ \\
\hline $17 R$ & 1 & $35-46$ & 47 & 038. & Vein $(\mathrm{Sa})$ & $3 \mathrm{~mm}$ \\
\hline $17 R$ & $i$ & $35-46$ & 35 & 041. & Vein (Sa) & $3 \mathrm{~mm}$ \\
\hline $17 R$ & $i$ & $35-46$ & 80 & 303 & Vein $(\mathrm{Sa})$ & $1-4 \mathrm{~mm}$ \\
\hline $17 \mathrm{R}$ & $i$ & $49-55$ & 75 & & Vein (Sa-Py) & $2 \mathrm{~mm}$ \\
\hline
\end{tabular}

during the formation of the faults was extensional, with sigma 2 and sigma 3 almost equivalent; the more gently dipping planes having low pitch angle may derive from reworked older faults. They affect strata up to the upper Miocene and crosscut already compacted sediments. However, they have not been noticed above 465 mbsf, whereas the fissility appears at the shallower depth of $263 \mathrm{mbsf}$. This observation and the absence of visible faults argue that a not recent tectonic event may be responsible for these faults. A faulting episode taking place at the end of the Miocene or soon after is likely.

The fourth group of faults is restricted within the Quaternary sediments, particularly from 11 to $13 \mathrm{mbsf}$ and from 50 to $65 \mathrm{mbsf}$, where they are often associated with slumps. All are normal faults (Pl. 1, Fig. 2). Comparing the apparent dip of fault planes in the core cut section with the orientation of cores by means of paleomagnetic measurements shows that these normal faults are mainly dipping either toward the northwest or toward the southeast azimuths. This is in agreement with the present stress field deduced from the elliptical cross section of the drill hole (Shipboard Scientific Party, 1990c), which indicates that northeast-southwest and northwest-southeast directions correspond respectively to the present maximum and minimum horizontal main stresses.

In addition, five healed faults having an apparent reverse offset were observed in Hole 799B (Pl. 1, Fig. 3). Some are clearly related to slump structures and associated normal faults. All can be interpreted as an early bedding-parallel shearing on a slope (Shipboard Scientific Party, 1990c). No real compressive phase was documented.

In summary, the fractures observed in Site 798 and 799 cores reveal a general extensional regime from the early Miocene to the Holocene at Site 799. This regime is well expressed by the early faults developed in the middle Miocene sediments of the Kita-Yamato Trough. There, a rather prominent phase of faulting that produced slickensided normal faults and normal strike-slip faults occurred probably at the end of the Miocene or beginning of the Pliocene. The Pliocene sediments of the Oki Ridge display a few synsedimentary normal faults. The latest period of marked tectonic instability, documented by normal faults and association of normal faults and slumps, began in the latest Pliocene, better expressed in the Kita-Yamato Trough sedimentary pile.

\section{GENERAL DISCUSSION: RELATIONSHIP OF STRUCTURES TO THE TECTONIC EVOLUTION OF THE JAPAN SEA}

Questions of the age and kinematics of the formation of the Japan Sea are controversial. Proposed ages range from Cretaceous to late Miocene (see review in Ingle, Suyehiro, von Breymann, et al., 1990). 


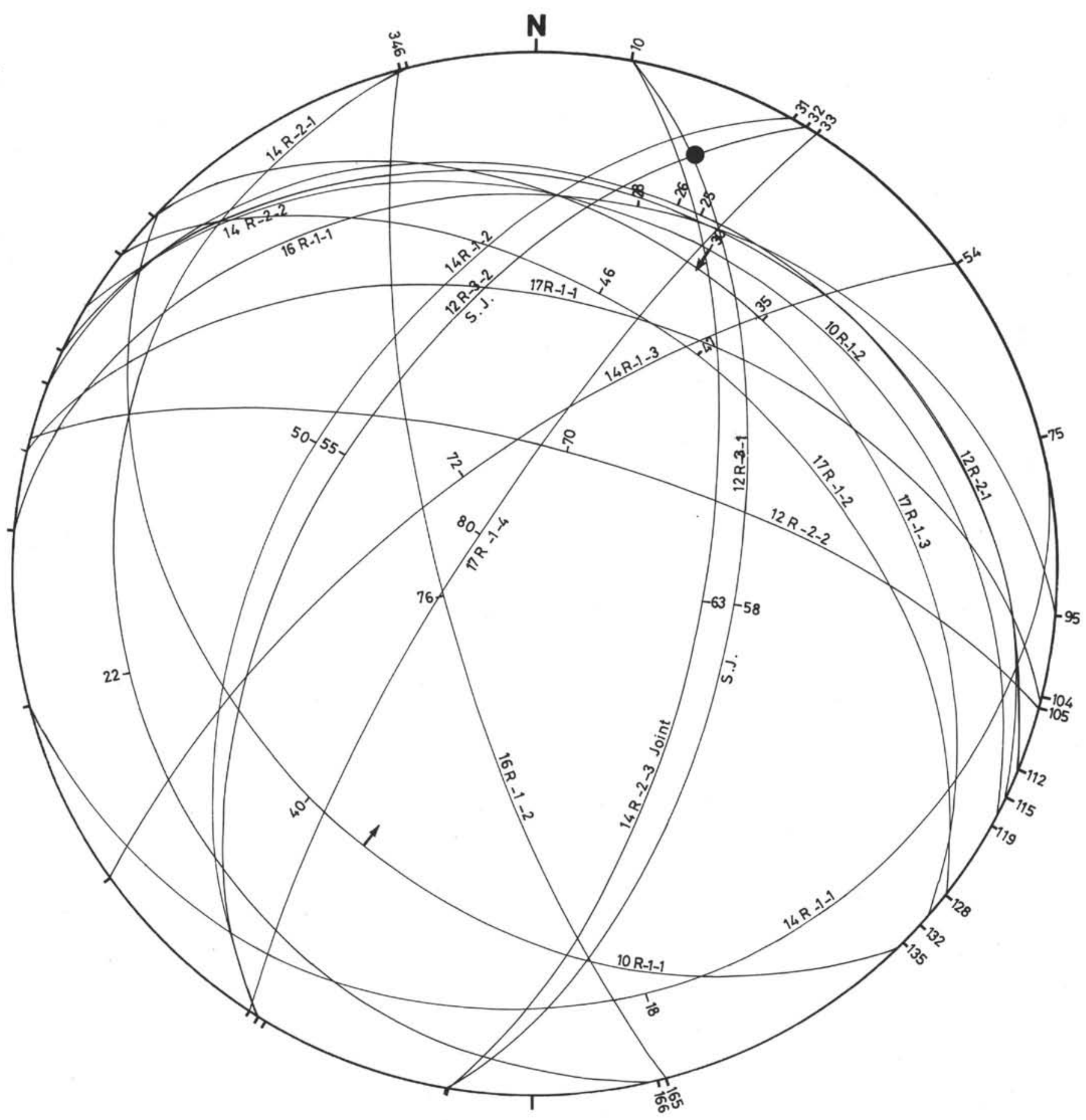

Figure 4. Stereoplot of Hole 794D fractures, oriented from paleomagnetic measurements. The solid circle shows the intersection of an assumed conjugate set. Fractures are numbered according to the core and section numbers and their rank in the section; for instance the fracture 14R-1-2 is the second fracture measured in Core 14R, Section 1.

However, evidence coming from offshore and onshore geology suggested that prior to ODP drilling the formation of the Japan Sea was initiated in late Oligocene to early Miocene time (Tamaki, 1988; Jolivet et al., 1989; Ingle, Suyehiro, von Breymann, et al., 1990). The inferred duration of the opening, deduced from paleomagnetic studies and onshore geological survey, was also variable (e.g., Otofuji et al., 1985; Lallemand and Jolivet, 1986; Otofuji and Matsuda, 1987; Jolivet et al., 1989). Recent studies pointed out a period of compression that took place since about $2 \mathrm{Ma}$ on the eastern border of the
Japan Sea, which was marked by compressional earthquakes, folds, and reverse faults (Fukao and Furumoto, 1975; Nakamura, 1983; Lallemand et al., 1985; Tamaki and Honza, 1985; Jolivet, 1986; Tamaki, 1988). Just before Leg 128, drilling during Leg 127 at Site 796 on the Okushiri Ridge permitted the dating of the initial uplift of this ridge caused by that compression as $1.8 \mathrm{Ma}$, in agreement with the general evidence of a late Pliocene-early Pleistocene compressive deformation along the eastern margin of the Japan Sea. Very different kinematic models have also been proposed (see review in Ingle, 


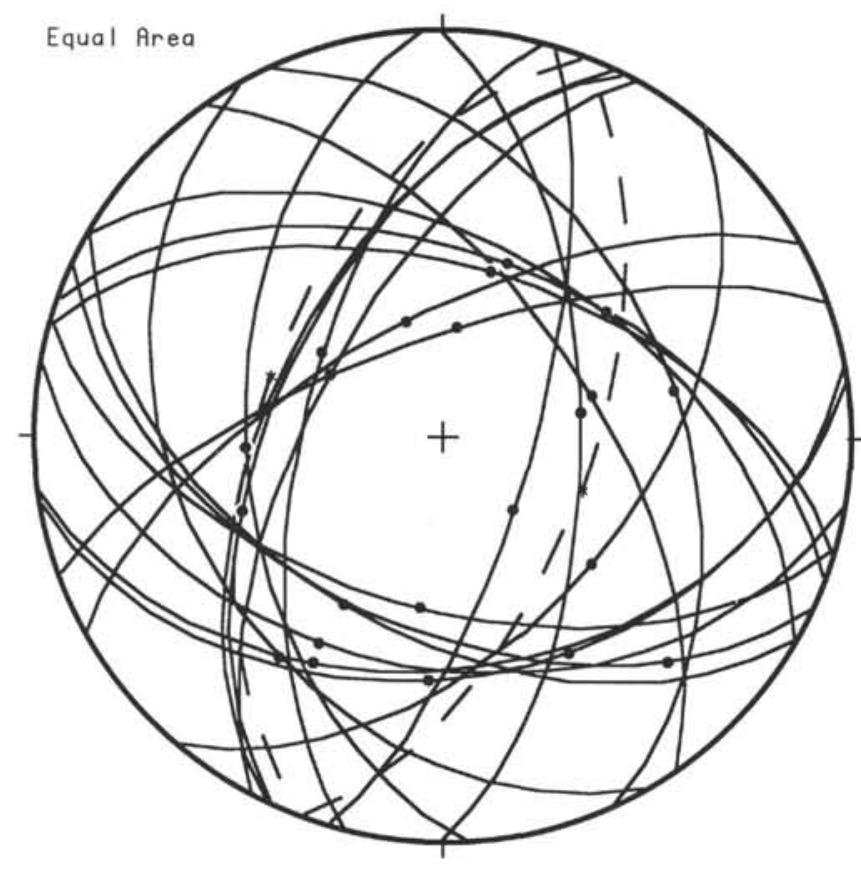

Figure 5. Stereoplot of slickensided faults from Site 799, oriented from paleomagnetic data.

Suyehiro, von Breymann, et al., 1990). Most of these models imply differential rotations of southwest and northeast Japan, based on paleomagnetic studies (e.g., Otofuji et al., 1985; Otofuji and Matsuda,1987; Celaya and McCabe, 1987; Hirooka, 1987; Tosha and Hamano, 1988) or on onshore geology, especially for the clockwise rotation of southwest Japan (Faure and Lalevée, 1987; Fabbri et al., 1987; Charvet et al., 1990; Jolivet et al., 1990). In contrast, the initial pull-apart model (Lallemand and Jolivet, 1986), which emphasized the role of regional right-lateral strike-slip faults, admitted no rotation at all; then, models reconciling intraplate and interplate shear and rotation were proposed (Tamaki, 1988; Jolivet et al., 1989). Of course, the inferred stress distributions are not identical in the case of classic back-arc opening, which implies a steadily extensional regime, and in the case of the pull-apart opening that involves transpressive to transtensional regimes. The data collected during Legs 127 (Tamaki, Pisciotto, Allan, et al., 1990) and 128 (Ingle, Suyehiro, von Breymann, et al., 1990) permit a new kinematic synthesis of the Japan Sea opening (Jolivet and Tamaki, this volume), using the new timing constraints, the changing stress across the whole Japanese arc area, and the evolution of volcanism. We summarize how the structural features described above can meet some aspects of the general tectonic evolution of the Japan Sea and its bordering arc.

The most valuable information comes from the fault and vein development deduced from Hole 794D cores. If our conclusion is valid, the stress regime alternating north-northeast to south-southwest compression and west-northwest to east-southeast extension during the late early Miocene to early middle Miocene time is fairly consistent with the stress system and the right-lateral transpressive to transtensional deformation occurring at that time from Hokkaido to western Honshu (Kimura and Tamaki, 1986; Jolivet, 1986; Tamaki, 1988; Jolivet and Huchon, 1989). Consequently, it supports the hypothesis of a pull-apart mechanism resulting from a right-lateral shear along the eastern side of the Japan Sea (Lallemand and Jolivet, 1986; Jolivet, 1986; Jolivet and Tamaki, this volume). The principal stress directions inferred from fault set analysis at Site 794 can be discussed in the framework of the tectonic evolution of the whole eastern margin. In Figure 6, we show a tectonic sketch of the entire back-arc domain, including Sakhalin, after Jolivet et al. (in press), reconstructed at $20 \mathrm{Ma}$. The geometry of reconstruction obeys the kinematics described in Jolivet and Tamaki (this volume). The principal stress directions are drawn after Yamagishi and Watanabe (1986), Otsuki (1989; 1990), Jolivet and Huchon (1989), and Jolivet et al. (1991). Principal horizontal stress directions show that the stress regime evolved from a dextral transpression in the northern part (Sakhalin and Hokkaido) to a dextral transtension in the south (Jolivet and Tamaki, this volume). The north-northeast direction of compression deduced from the data obtained at Site 794 is in full agreement with this reconstruction for the early Miocene time. The alternation of northeast compression and northwest extension also was observed in the field for the early to middle Miocene period, in Sado Island and Noto Peninsula (Jolivet et al., 1991; Jolivet et al., in press). By contrast, such a direction of compression is different from the attitude of sigma 1 in Holocene time (Jolivet et al., in press; Jun, 1990). Note that Site 794 is the northeasternmost site of Leg 128 and is nearest the inferred main shear zone of the strike-slip system. The later structures (younger than $16 \mathrm{Ma}$, observed in Hole 794D) reveal an extensional or transtensional regime without orientation. No evidence of recent compression was found, and this can also be discussed. If the recent east-west compression can be clearly observed along the eastern margin of the Japan Sea, from Hokkaido to Sado Island, it cannot be observed in Noto Peninsula. This is confirmed by the fact that Sado Island is actively uplifting, whereas Noto Peninsula is not. Both Site 794 and Noto Peninsula thus are located to the west of the zone of active compressive deformation, which might be bounded by the Itoigawa-Shizuoka Tectonic Line and its northern extension offshore (see below).

Also significant is the evidence of late Miocene or early Pliocene faulting responsible for the steep slickensided faults in Site 799 cores. This fits with the evidence for deepening of the Kita-Yamato Trough provided by the benthic foraminiferal assemblage (Shipboard Scientific Party, 1990c), and the resumption of volcanism, both at the beginning of the Pliocene. This faulting phase corresponds to the "second tectonic stage" of Honza (1979) and is consistent with the onlapping of the "stratified layer" onto the "transparent layer," reported from the seismic profiles around the Yamato Ridge (Tamaki, 1988 ) and the age proposed for this disconformity (Karig, Ingle, et al., 1975). This phase also agrees with the onlapping seen in seismic lines that cross the Yamato Trough. It may correspond to the redistribution of stress that occurred during the late Miocene and early Pliocene in the arc area, transition from extensional to compressional (Jolivet and Tamaki, this volume).

At Site 798 on the Oki Ridge, no evidence of compression was found. Although a late Pliocene-early Pleistocene uplift of the ridge is probable (Shipboard Scientific Party, 1990b), the compressional deformation known at that time on the eastern side of the Japan Sea (e.g., Ingle, 1975, 1981; Morozumi and Koizumi, 1981; Ishiwada et al., 1984; Lallemand et al., 1985; Jolivet, 1986; Tamaki, 1988; Tamaki, Pisciotto, Allan, et al., 1990) is not documented in the sedimentary pile on top of the ridge. The reason may be that this compressive deformation still is restricted to the north of the ItoigawaShizuoka Tectonic Line, along which a northwest-west-northwest to southeast-east-southeast compression is occurring (Fukao and Yamaoka, 1983). If the Itoigawa-Shizuoka Tectonic Line acted as a main boundary, it also might explain why the Quaternary Izu collision on the Pacific side of Central Japan has not been recorded as well, nor, in the Pliocene strata, the Tanzawa collision that preceded the Izu one (Niitsuma and Matsuda, 1985; Huchon and Angelier, 1987; Charvet and Fabbri, 1987). However, for the last one, a simple reason may be linked to the age of the oldest sediments recovered, which dated as late early Pliocene (Shipboard Scientific Party, 1990c) might post-date the Tanzawa collision.

In addition, at Site 799 the latest Pliocene resumption of tectonic activity is marked by normal faults and slumps. The horizontal section of the strain ellipsoid, measured during logging in Hole 799A, indicates a maximum horizontal main stress in the northeast-southwest 


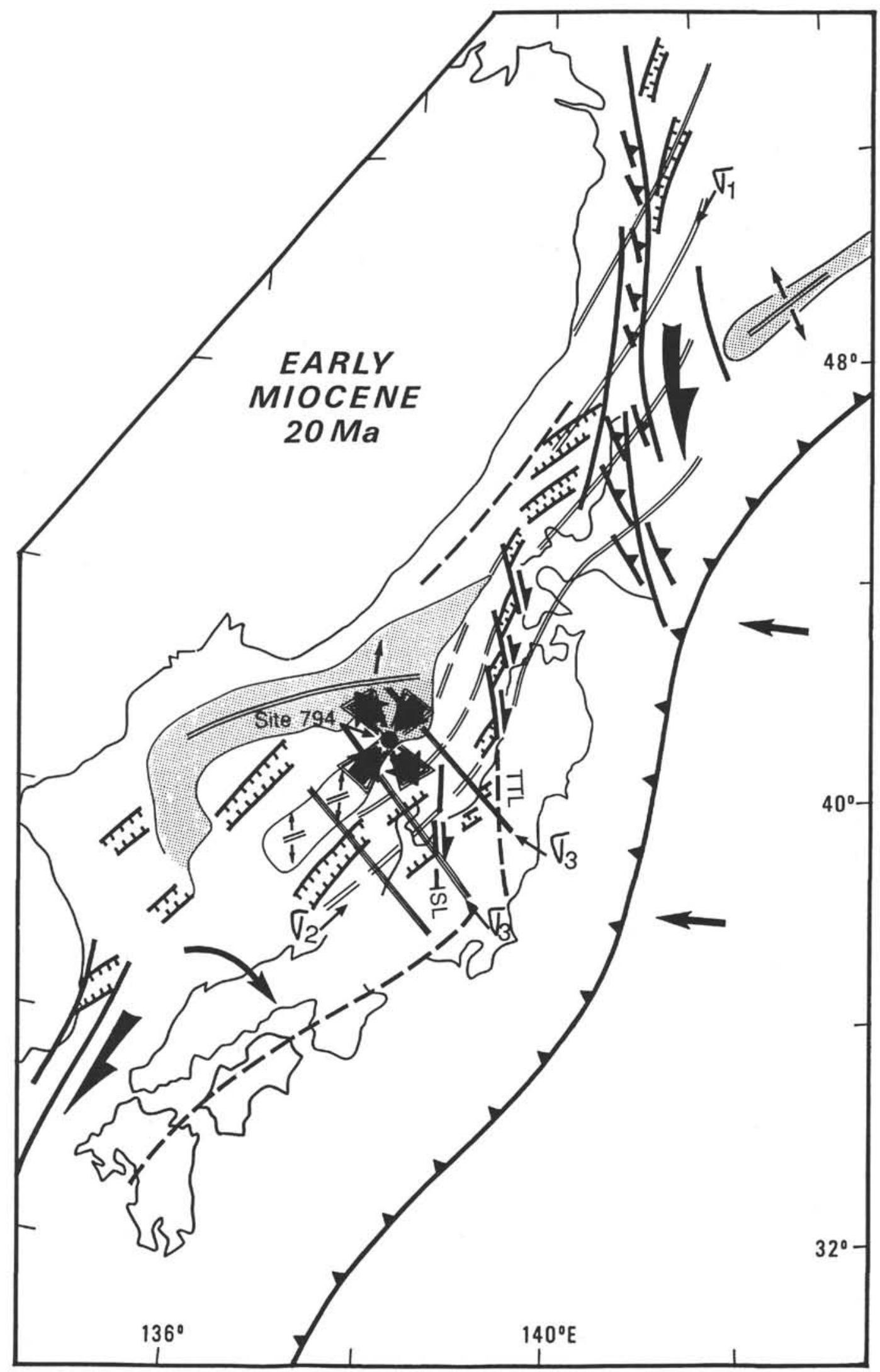

Figure 6. Tectonic sketch of the Japan Sea area reconstructed at $20 \mathrm{Ma}$, modified after Jolivet et al. (in press) and Jolivet and Tamaki (this volume). The principal stress trajectories are drawn after Yamagishi and Watanabe (1986), Otsuki (1989, 1990), Jolivet and Huchon (1989), and Jolivet et al. (1991). Wide arrows around Site 794 show the principal stress directions deduced from the structures in the cores. Note that the directions of compression and extension for the lower to middle Miocene time fit with the general stress distribution reconstructed from other data. 
direction, parallel to the Kita-Yamato Trough, and the minimum one in the northwest-southeast direction. Based on our fault observations, the real maximum main stress is probably still vertical.

The abundance of veins and early normal microfaults in the lower to middle Miocene sediments indicates a prominent extensional regime at that time, which is consistent with the rapid subsidence of this graben (Shipboard Scientific Party, 1990c). The scarcity or absence of these features during the late Miocene and Pliocene may support the hypothesis of a phase of large extension of the Kita-Yamato and Yamato area that was already completed at that time. This observation fits with the general timing of the Japan Sea opening (Jolivet and Tamaki, this volume). In particular, it is consistent with the rotation of southwest Japan (as documented by onshore geology) that was completed by about 15 Ma (Fabbri et al., 1987; Charvet et al., 1990).The bulk of information suggests that the opening of the Yamato Basin and main subsidence of the Kita-Yamato Trough occurred between 20 and $15 \mathrm{Ma}$, and one can argue that it ceased as a result of the Philippine Sea Plate's encountering the southwest Japan Arc (Jolivet and Tamaki, this volume). However, if we accept the collisional model for the Shimanto belt (Charvet, 1980), the likely colliding feature was driven by the Philippine Sea Plate: either the frontal arc of this plate (Charvet and Fabbri, 1987; Charvet et al., 1990) or its young oceanic lithosphere (Hibbard and Karig, 1990). Had this collision occurred earlier, perhaps as soon as $21 \mathrm{Ma}$ (Charvet and Fabbri, 1987), by 16 to $15 \mathrm{Ma}$ the tectonic regime would have been extensional during the emplacement of the Shimanto granites, post-dating the southwest Japan bending (Charvet et al., 1990). Thus, an alternative model is that the Yamato area main extension and opening post-dated the Shimanto collision, which induced a compressive stress regime, and ceased at about $15 \mathrm{Ma}$ for an unclear reason, perhaps linked to the Central Japan evolution that involved the Izu Arc collision.

\section{CONCLUSIONS}

Several structural features were observed in the Leg 128 cores that permit some conclusions about the genesis and tectonic environment of these features and the tectonic evolution of the Japan Sea.

1. Gravity-induced structures, mainly slumps and associated faults, suggest the existence of paleoslopes and extensional and gravitational tectonics during early and middle Miocene, near the Pliocene/Quaternary boundary, and during the Quaternary.

2. Many dewatering veins were encountered, especially within the middle Miocene siliceous claystones and porcellanites from the KitaYamato Trough. They are interpreted as fractures that form preferentially in highly porous, organic-rich, fluid-overpressured sediments, such as diatomaceous muds, as a result of episodic loss of sediment strength allowing fluid escape. They are active only once, as a fluid conduit ending with branching extremities, where the transition to intergranular flow occurs. The probable trigger is seismic activity linked to faulting in a local extensional regime. The bedding-parallel shear couple is probably from gravity gliding on a slope.

3. The various fractures reported from Hole 794D and Site 798 and 799 cores suggest a prominent early to middle Miocene extensional environment in the Kita-Yamato Trough, a likely transpressive to transtensional regime around the early Miocene/middle Miocene boundary in the northeast part of the Yamato Basin, a late Mioceneearly Pliocene phase of faulting well recorded in the Kita-Yamato Trough, and a final faulting beginning in the latest Pliocene. At Sites 798 and 799 , the general tectonic regime was extensional.

4. These data fit with a pull-apart model of the Japan Sea opening in the early Miocene-middle Miocene. They address the question of the relationship between the Yamato Basin opening and the collision of southwest Japan with the Philippine Sea Plate.

\section{ACKNOWLEDGMENTS}

This study was supported by a grant from CNRS/INSU: 90/ATP/780/AP90, 8039 10, GEO 3.03. Y. Ogawa and an anonymous reviewer are thanked for their help in improving the manuscript.

\section{REFERENCES}

Angelier, J., Bergerat, F., and Colletta, B., 1983. Les variations du rapport entre les composantes en extension et en décrochement: golfe de Suez, fossés ouest-européens et ouest-anatoliens, "Basins and Ranges" et golfe de Californie. In Charvet, J. (Ed.), Tectonique Cassante en Distension et Coulissement. Coll., Orléans, Soc. Geol. Nord, Villeneuve d'Ascq, Res. Com., 2-3.

Arthur, M. A., Carson, B., and von Huene, R., 1980. Initial tectonic deformation of hemipelagic sediments at the leading edge of the Japan convergent margin. In von Huene, R., Nasu, N., et al., Init. Repts. DSDP, 56, 57 (Pt. 1): Washington (U.S. Govt. Printing Office), 569-613.

Bagnold, R. A., 1954. Experiments on a gravity-free dispersion of large solid spheres in a Newtonian fluid under shear. Proc. R. Soc. London A, 225:49-63.

Barrière, M., 1976. Flowage differentiation: limitation of the "Bagnold effect" to the narrow intrusions. Contrib. Mineral. Petrol., 55:139-145.

Bergerat, F., 1989. From pull-apart to the rifting process: the formation of the Pannonian basin. Tectonophysics, 157:271-280.

Bhattacharji, S., and Savic, P., 1965. Real and apparent non-newtonian behavior in viscous pipe flow of suspension driven by a fluid pression. In Charwat, A. F., et al. (Eds.), Heat Transfer and Fluid Mechanics. Inst. Proc. Stanford Univ., 248-262.

Bhattacharji, S., and Smith, C. H., 1964. Flowage differentiation. Science, 145:150-153.

Brown, K. M., and Behrmann, J., 1990. Genesis and evolution of small-scale structures in the toe of the Barbados Ridge accretionary wedge. In Moore, J. C., and Mascle, A., et al., Proc. ODP, Sci. Results, 110: College Station, TX (Ocean Drilling Program), 229-244.

Carson, B., von Huene, R., and Arthur, M., 1982. Small-scale deformation structures and physical properties related to convergence in Japan Trench slope sediments. Tectonics, 1:277-302.

Celaya, M., and McCabe, R., 1987. Kinematic model for the opening of the Sea of Japan and the bending of the Japanese Islands. Geology, 15:53-57.

Charvet, J., 1980. Subduction et tectonique: quelques réflexions sur "l'orogenèse de type Pacifique" à propos du Japon sud-ouest. C. R. Somm. Soc. Geol. Fr., 2:58-61.

Charvet, J., and Fabbri, O., 1987. Vue générale sur l'orogenèse Shimanto et l'évolution tertiaire du Japon sud-ouest. Bull. Soc. Geol. Fr., 8:1171-1188.

Charvet, J., Faure, M., Fabbri, O., Cluzel, D., and Lapierre, H., 1990. Accretion and collision during east-asiatic margin building. A new insight on the peri-Pacific orogenies. In Wiley, T. J., Howell, D. G., and Wong, F. L. (Eds.), Terrane Analysis of China and the Pacific Rim. Circum-Pac. Counc. Energy Mineral Resour., Earth Sci. Ser., 13:161-185.

Cowan, D. S., 1982. Origin of "vein structures" in slope sediments on the inner slope of the Middle America Trench off Guatemala. In Aubouin, J., von Huene, R., et al., Init. Repts. DSDP, 67: Washington (U.S. Govt. Printing Office), 645-650.

Fabbri, O., Charvet, J., and Faure, M., 1987. Sur la déformation associée à la rotation de Kyushu (Japon $\mathrm{SW}$ ), au Miocène moyen. C. R. Acad. Sci. Ser. 2, 304:1207-1212

Faure, M., and Lalevée, F., 1987. Bent structural trends of Japan. Flexural slip folding related to the Neogene opening of the Sea of Japan. Geology, 15:49-52.

Fukao, Y., and Furumoto, M., 1975. Mechanism of large earthquakes along the eastern margin of the Japan Sea. Tectonophysics, 25:247-266.

Fukao, Y., and Yamaoka, K., 1983. Stress estimate for the highest mountain system in Japan. Tectonics, 2:453-471.

Garrison, R. E., Douglas, R., Pisciotto, K., Isaacks, C., and Ingle, J. C. (Eds.), 1981. The Monterey Formation and Related Siliceous Rocks of California. Spec. Publ.-Soc. Econ. Paleontol. Mineral., Pacific Sect., 15.

Grimm, K. A., 1990. Intrastratal microfractured zones in laminated Miocene diatomites from the Monterey Formation, California: a clue to Miocene paleoseismology? Trans. Am. Geophys. Union, 71:1633. 
1991. Intrastratal microfractured zones in laminated Miocene diatomaceous sediments from the Monterey Formation, California: a record of Miocene paleoseimicity? AAPG Bull., 75:366.

Helm, R., and Vollbrecht, A., 1985. Brittle ductile shear zones in slope sediments off Guatemala, Sites 568 and 569, Deep Sea Drilling Project Leg 84. In von Huene, R., Aubouin, J., et al., Init. Repts. DSDP, 84: Washington (U.S. Govt. Printing Office), 625-632.

Hibbard, J. P., and Karig, D. E., 1990. Alternative plate model for the early Miocene evolution of the southwest Japan margin. Geology, 18:170-174.

Hill, P. R., and Marsters, J. C., 1990. Controls on physical properties of Peru continental margin sediments and their relationship to deformation styles. In Suess, E., von Huene, R., et al., Proc. ODP, Sci. Results, 112: College Station,TX (Ocean Drilling Program), 623-632.

Hirooka, K., 1987. Opening of the Japan Sea and the Neogene tectonic event of the Japanese inferred from paleomagnetism. In Tsuchi, R. (Ed.), Pacific Neogene Event: Shizuoka (Shizuoka Univ.), 29-31.

Holler, P., 1986. Fracture activity: a possible triggering mechanism for slope instabilities in the eastern Atlantic? Geo-Mar. Lett., 5:211-216.

Honza, E., 1979. Sediments, structure and origin of Japan Sea-concluding remarks. In Honza, E. (Ed.), Geological Investigation of the Japan Sea, Cruise Report 13. Geol. Surv. Jpn., 89-93.

Huchon, P., and Angelier, J., 1987. From subduction to collision: the SurugaFujigawa belt, Izu collision zone. Bull Soc. Geol. Fr., 8:511-521.

Ingle, J. C., Jr., 1975. Summary of late Paleogene-Neogene stratigraphy, paleobathymetry, and correlations, Philippine Sea and Sea of Japan region. In Karig, D. E., Ingle, J. C., Jr., et al., Init. Repts. DSDP, 31: Washington (U.S. Govt. Printing Office), 837-855.

1981. Origin of Neogene diatomites around the North Pacific rim In Garrison, R. E., Douglas, R., Pisciotto, K., Isaacks, C., and Ingle, J. C., The Monterey Formation and Related Siliceous Rocks of California. Spec. Publ.-Soc. Econ. Paleontol. Mineral., Pacific Sect., 15:159-179.

Ingle, J. C., Jr., Suyehiro, K., von Breymann, M. T., et al., 1990. Proc. ODP, Init. Repts., 128: College Station, TX (Ocean Drilling Program).

Ishiwada, Y., Honza, E., and Tamaki, K., 1984. Sedimentary basins of the Japan Sea. Proc. 27th Int. Geol. Congr., 23:43-65.

Jolivet, L., 1986. America-Eurasia plate boundary in eastern Asia and the opening of marginal basins. Earth Planet. Sci. Lett., 81:282-288.

Jolivet, L., Fournier, M., Huchon, P., Rozhdestvenskiy, V. S., Sergeyev, K. F., and Oscorbin, L. S., in press. Cenozoic intracontinental dextral motion in the Okhostk-Japan Sea region. Tectonics.

Jolivet, L., and Huchon, P., 1989. Crustal scale strike-slip deformation in Hokkaido, northeast Japan. J. Struct. Geol., 11:509-522.

Jolivet, L., Huchon, P., Brun, J. P., Chamot-Rooke, N., Le Pichon, X., and Thomas, J. C., 1991. Arc deformation and marginal basin opening: Japan Sea as a case study. J. Geophys. Res., 96:4347-4384.

Jolivet, L., Huchon, P., and Rangin, C., 1989. Tectonic setting of western Pacific marginal basins. Tectonophysics, 160:23-48.

Jun, M. S., 1990. Source parameters of shallow intraplate earthquakes in and around the Korean peninsula and their tectonic implication. Acta Universitatis Uppsaliensis: Comprehensive Summaries of Uppsala Dissertation from the Faculty of Science, Uppsala, 285.

Karig, D. E., Ingle, J. C., Jr., et al., 1975. Init. Repts. DSDP, 31: Washington (U.S. Govt. Printing Office).

Keller, G. H., 1983. Coastal upwelling: its influence on the geotechnical properties and stability characteristics of submarine deposits. In Thiede, J., and Suess, E. (Eds.), Coastal Upwelling: Its Sediment Record (Pt. A): New York (Plenum), 181- 199.

Kemp, A.E.S., 1990. Fluid flow in "vein structures" in Peru forearc basins: evidence from back scattered electron microscope studies. In Suess, E., von Huene, R., et al., Proc. ODP, Sci. Results, 112: College Station, TX (Ocean Drilling Program), 33-41.

Kimura, G., and Tamaki, K., 1986. Collision, rotation and back arc spreading: the case of the Okhotsk and Japan seas. Tectonics, 5:389-401

Knipe, R. J., 1986. Microstructural evolution of vein arrays preserved in Deep Sea Drilling Project cores from the Japan Trench, Leg 57. In Moore, J. C. (Ed.), Structural Fabrics in Deep Sea Drilling Project Cores From Forearcs. Mem.-Geol. Soc. Am., 166:75-88.

Komar, P. D., 1972. Mechanical interactions of phenocrysts and flow differentiation of igneous dikes and sills. Geol. Soc. Am. Bull., 83:973-988.

Lallemand, S., and Jolivet, L., 1986. Japan Sea, a pull-apart basin? Earth Planet. Sci. Lett., 76:375-389.

Lallemand, S., Okada, H., Otsuka, K., and Labeyrie, L, 1985. Tectonique en compression sur la marge est de la mer du Japon: mise en évidence de chevauchements à vergence orientale. C. R. Acad. Sci. Ser. 2, 301:201-206.
Lindsley-Griffin, N., Kemp, A., and Swartz, F., 1990. Vein structures of the Peru margin, Leg 112. In Suess, E., von Huene, R., et al., Proc. ODP, Sci. Results, 112: College Station TX (Ocean drilling Program), 3-16.

Lundberg, N., and Karig, D. E., 1986. Structural features in cores from Nankai Trough, Deep Sea Drilling Project Leg 87A. In Kagami, H., Karig, D. E., Coulbourn, W. C., et al., Init. Repts. DSDP, 87: Washington (U.S. Govt. Printing Office), 797-808.

Lundberg, N., and Moore, J. C., 1986. Macroscopic structural features in Deep Sea Drilling Project cores from forearc regions. In Moore, J. C. (Ed.), Structural Fabrics in Deep Sea Drilling Project Cores From Forearcs. Mem.-Geol. Soc. Am., 166:13-44.

Marsters, J. C., and Christian, H. A., 1990. Hydraulic conductivity of diatomaceous sediment from the Peru continental margin obtained during ODP Leg 112. In Suess, E., von Huene, R., et al., Proc. ODP, Init. Repts., 112: College Station, TX (Ocean Drilling Program), 633-638.

Morozumi, Y., and Koizumi, I., 1981. Himi and Yatsuo areas. In Tsuchi, R. (Ed.), Neogene of Japan. Geosci. Inst. Univ. Shizuoka.

Nakamura, K., 1983. Possible nascent trench along the eastern Japan Sea as the convergent boundary between Eurasia and North American plates. Tokyo Daigaku Jishin Kenkyusho Iho, 58:721-733.

Niitsuma, N., and Matsuda, T., 1985. Collision in the South Fossa Magna area, central Japan. Recent Progr. Natural Sci., 10:41-50.

Ogawa, Y., 1980. Beard-like veinlet structure as fracture cleavage in the Neogene siltstone in the Miura and Boso peninsulas, central Japan. Sci. Rep. Dept. Geol., Kyushu Univ., 13:321-327.

Ogawa, Y., and Miyata, Y., 1985. Vein structure and its deformational history in the sedimentary rocks of the Middle America Trench slope off Guatemala, Deep Sea Drilling Project Leg 84. In von Huene, R., Aubouin, J., et al., Init. Repts. DSDP, 84: Washington (U.S. Govt. Printing Office), $811-829$.

Otofuji, Y., and Matsuda, T., 1987. Amount of clockwise rotation of SW Japan-fan shaped opening of the southwestern part of the Japan Sea. Earth Planet. Sci. Lett., 85:289-301.

Otofuji, Y., Matsuda, T., and Nohda, S., 1985. Paleomagnetic evidence for the Miocene counter clockwise rotation of northeast Japan-rifting process of the Japan Sea. Earth Planet. Sci. Lett., 75:265-277.

Otsuki, K., 1989. Reconstruction of Neogene tectonic stress field of Northeast Honshu arc from metalliferous veins. Chishitsugaku Ronshu, 32:281-304. 1990. Neogene tectonic stress field of northeast Honshu arc and implications for boundary conditions. Tectonophysics, 181:151-164.

Reimers, C. E., 1982. Organic matter in anoxic sediments off central Peru: relations of porosity, microbial decomposition and deformation properties. Mar, Geol., 46:175-197.

Ritger, S. D., 1985. Origin of vein structures in the slope deposits of modern accretionary prisms. Geology, 13:437-439.

Shipboard Scientific Party, 1988. Site 673. In Mascle, A., Moore, J. C., et al., Proc. ODP, Init. Repts., 110: College Station, TX (Ocean Drilling Program), 311-388.

, 1990a. Site 794. In Ingle J. C., Jr., Suyehiro, K., von Breymann, M. T., et al., Proc. ODP, Init. Repts., 128: College Station, TX (Ocean Drilling Program), 67-120.

, 1990b. Site 798. In Ingle, J. C., Jr., Suyehiro, K., von Breymann, M. T., et al., Proc. ODP, Init. Repts., 128: College Station, TX (Ocean Drilling Program), 121-236.

1990c. Site 799. In Ingle, J. C., Jr., Suyehiro, K., von Breymann, M. T., et al., Proc. ODP, Init. Repts., 128: College Station, TX (Ocean Drilling Program), 237-402.

Tamaki, K., 1988. Geological structure of the Japan Sea and its tectonic implications. Chishitsu Chosasho Geppo, 39:269-365.

Tamaki, K., and Honza, E., 1985. Incipient subduction and obduction along the eastern margin of the Japan Sea. Tectonophysics, 119:381-406.

Tamaki, K., Pisciotto, K. A., Allan, J., et al., 1990. Proc. ODP, Init. Repts., 127: College Station, TX (Ocean Drilling Program).

Tosha, T., and Hamano, H., 1988. Paleomagnetism of Tertiary rocks from the Oga peninsula and the rotation of northeast Japan. Tectonics, 7:653-662.

Yamagishi, H., and Watanabe, Y., 1986. Change of stress field of Late Cenozoic in Southwest Hokkaido, Japan, investigation of geologic faults, dykes, ore veins and active faults. Monogr. Geol. Collabor. Jpn., 31:321-332.

Date of initial receipt: 17 April 1991

Date of acceptance: 28 February 1992

Ms 127/128B-238 


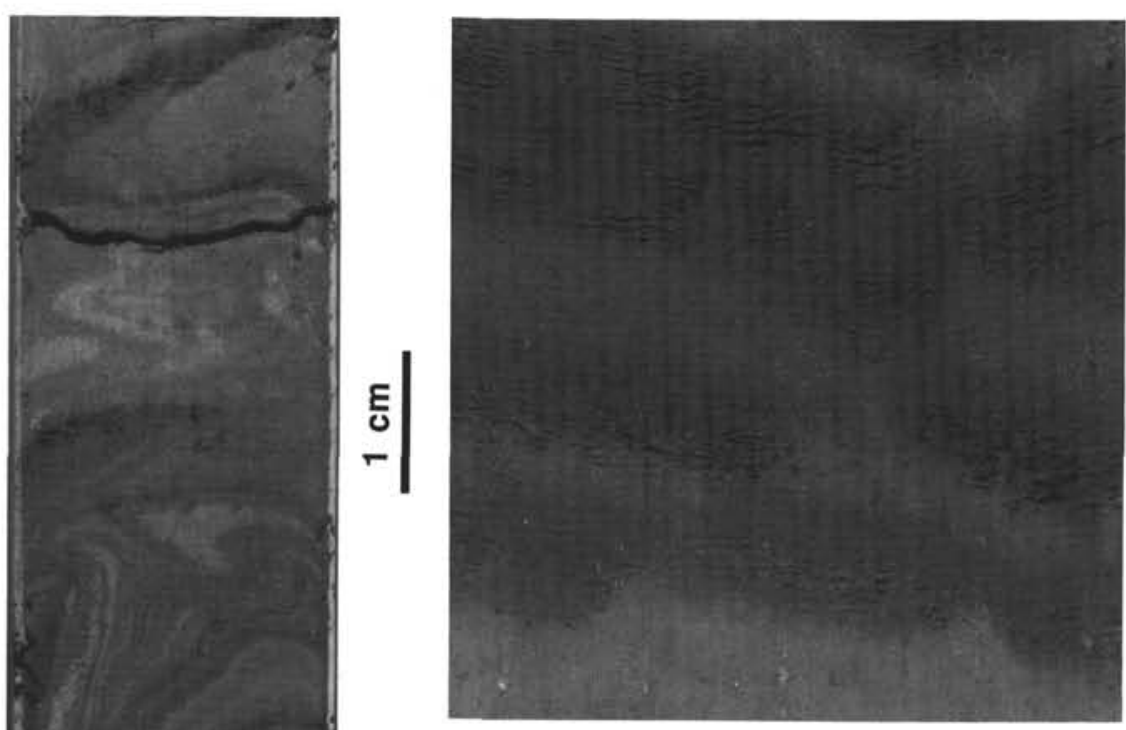

2
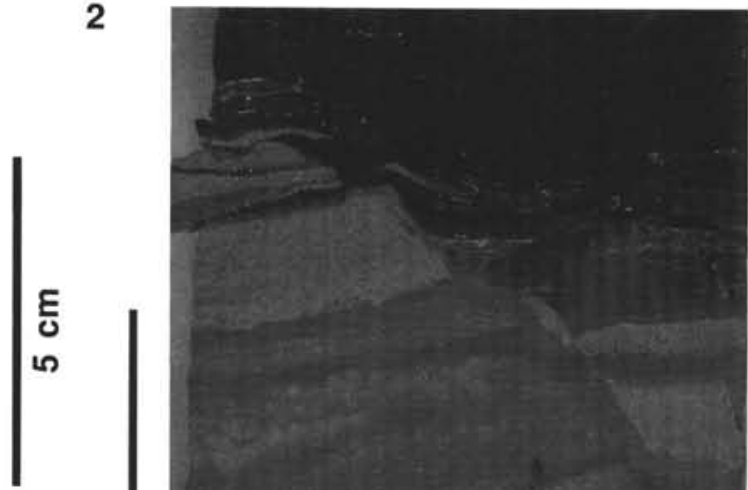

1

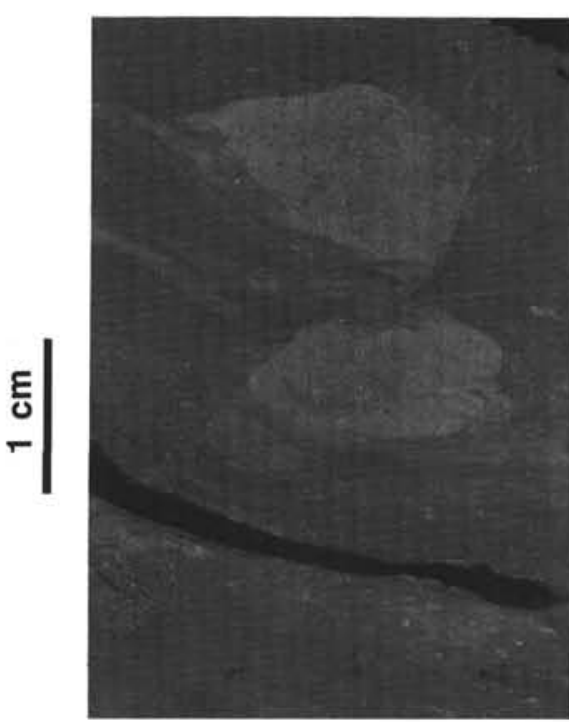

3

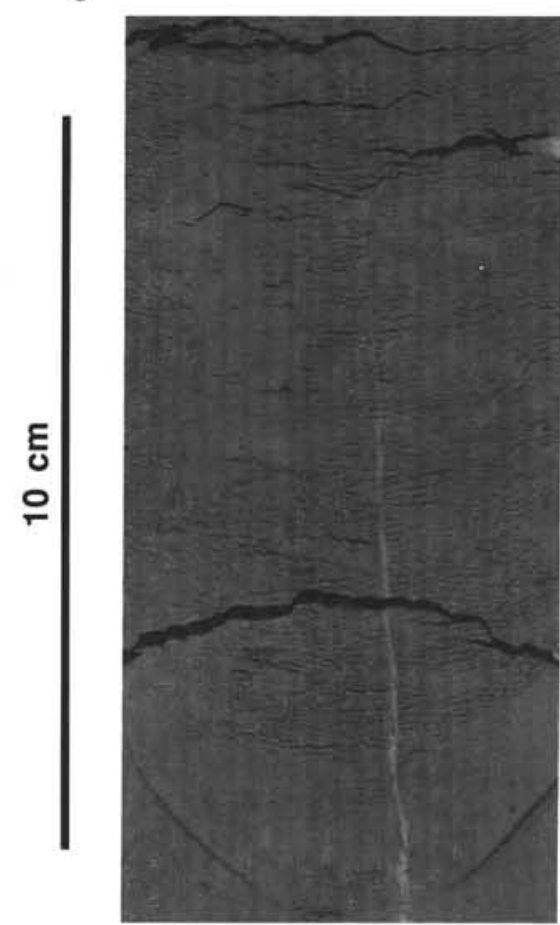

5

Plate 1. 1. Slump folds at interval 128-799A-6H-2,31-68 cm. 2. Normal fault in the Quaternary sediments at interval 128-799A-14H-1, 30-35 cm. 3. Apparent reverse fault in a slumped area at interval $128-799 \mathrm{~B}-3,127-133 \mathrm{~cm}$. 4. Normal fault with tilted blocks at interval $128-799 \mathrm{~B}-15 \mathrm{R}-4,100-109 \mathrm{~cm}$. Note the offset accommodation by differential compaction of the dark overlying clayey level. 5. White vein, likely filled tension gash, at interval 128-798A-5H-1, 137-149 cm. 

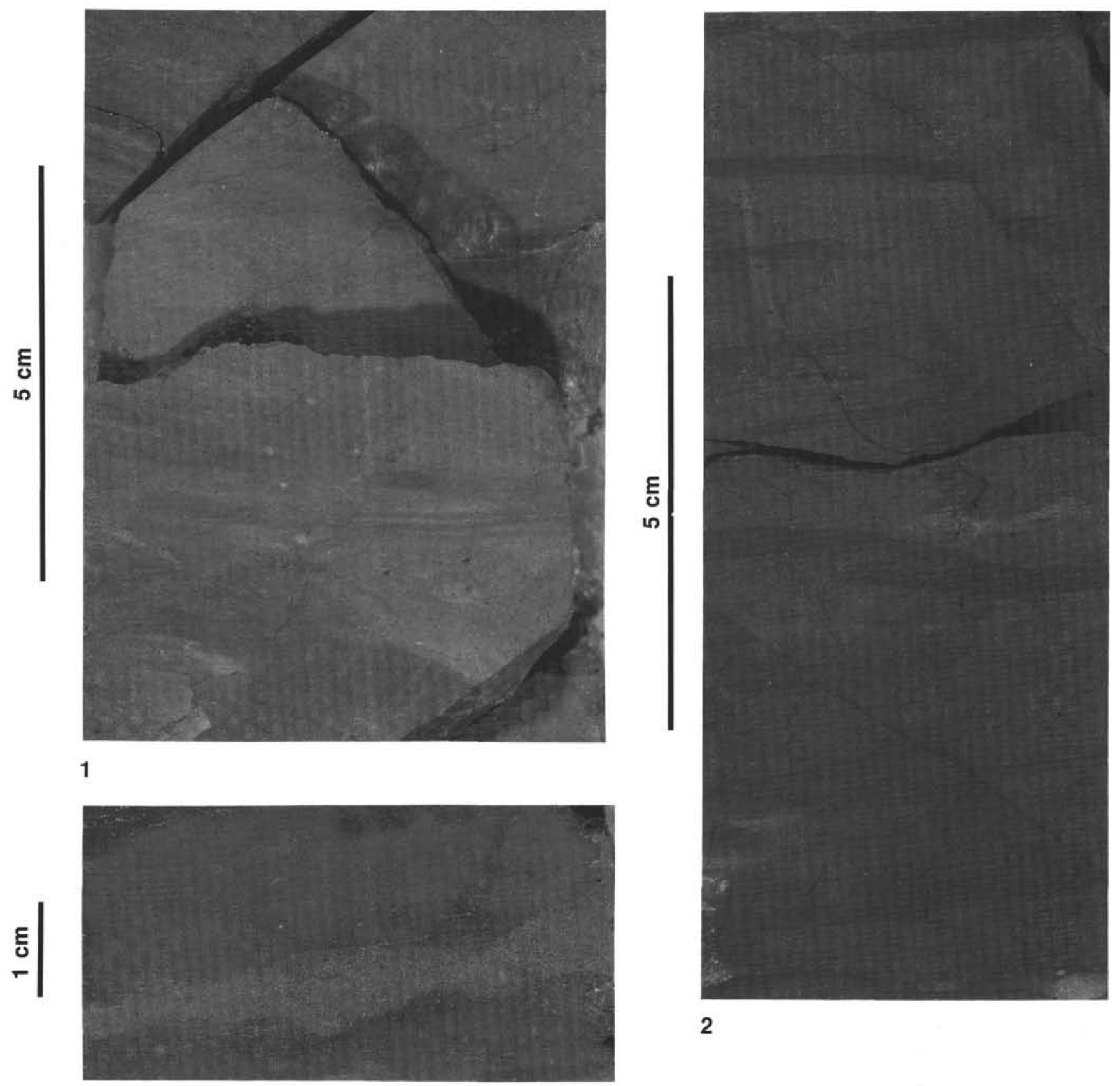

3

Plate 2. 1. Vein sets (including sigmoidal veins) and slickensided faults in siliceous claystones at interval 128-799B-24R-2, 34-42 cm. 2. Sigmoidal veins and healed normal faults, interval 128-799B-21R-1,95-108 cm. Note that the healed normal faults crosscut the sigmoidal veins, which in turn crosscut burrows. 3. Early normal fault offsetting a silty bed, interval $128-799 \mathrm{~B}-13 \mathrm{R}-2,77-81 \mathrm{~cm}$. 

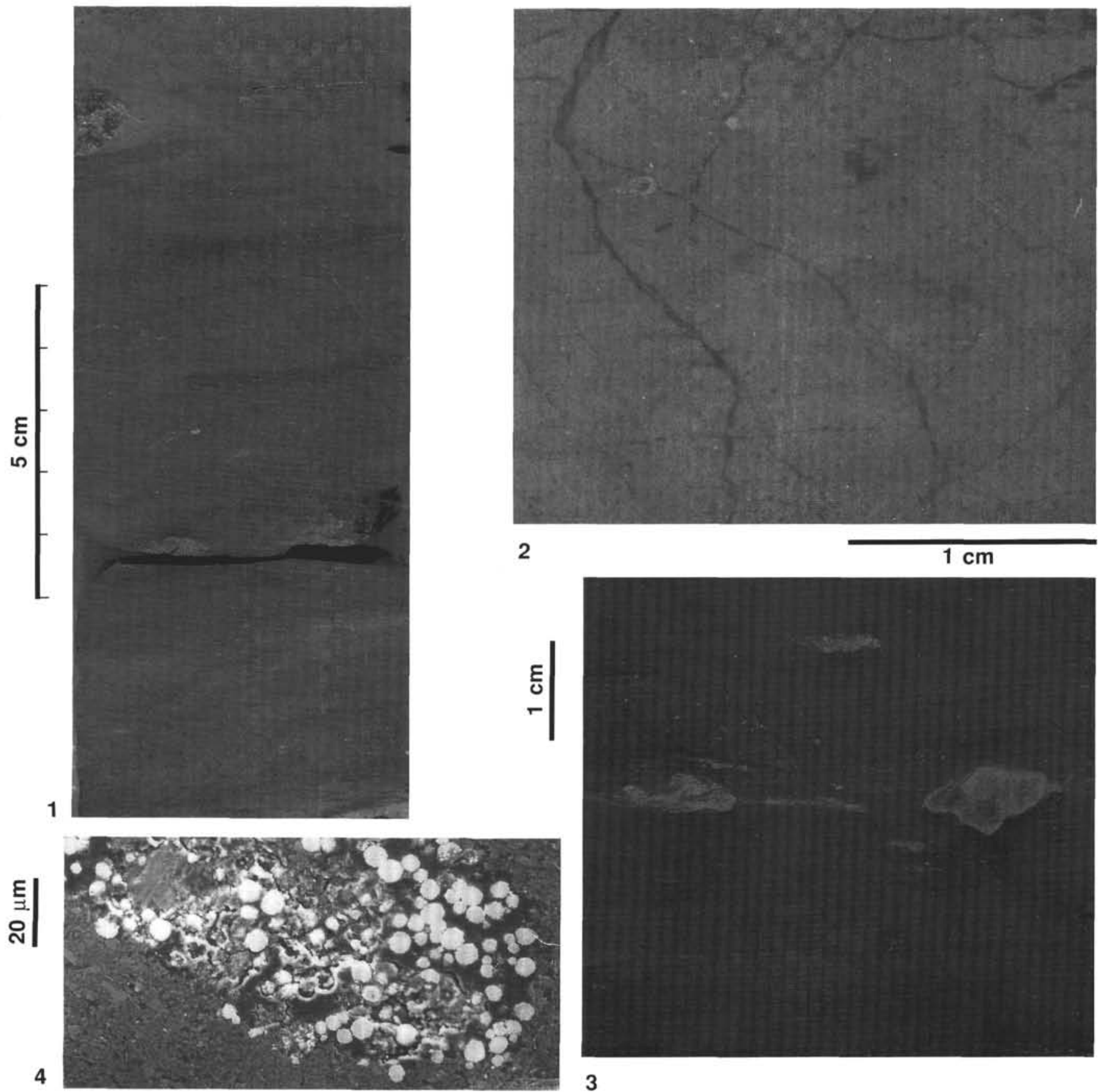

Plate 3. Dewatering veins. 1. Sigmoidal and anastomosing veins in siliceous claystones at interval 128-799B-25R-1, 129-140 cm. 2. Photomicrograph of anastomosing veins, Section 128-799B-23R-3 at 5-10 cm. Note the fine-grained fill. 3. Set of parallel sigmoidal veins at interval 128-799B-27R-2, 109-114 cm. Note the normal offset of the authigenic carbonate concretions. 4. BSEI photograph of a vein showing concentration of coarse-grained material in a very fine matrix: clay or amorphous silica(?). 

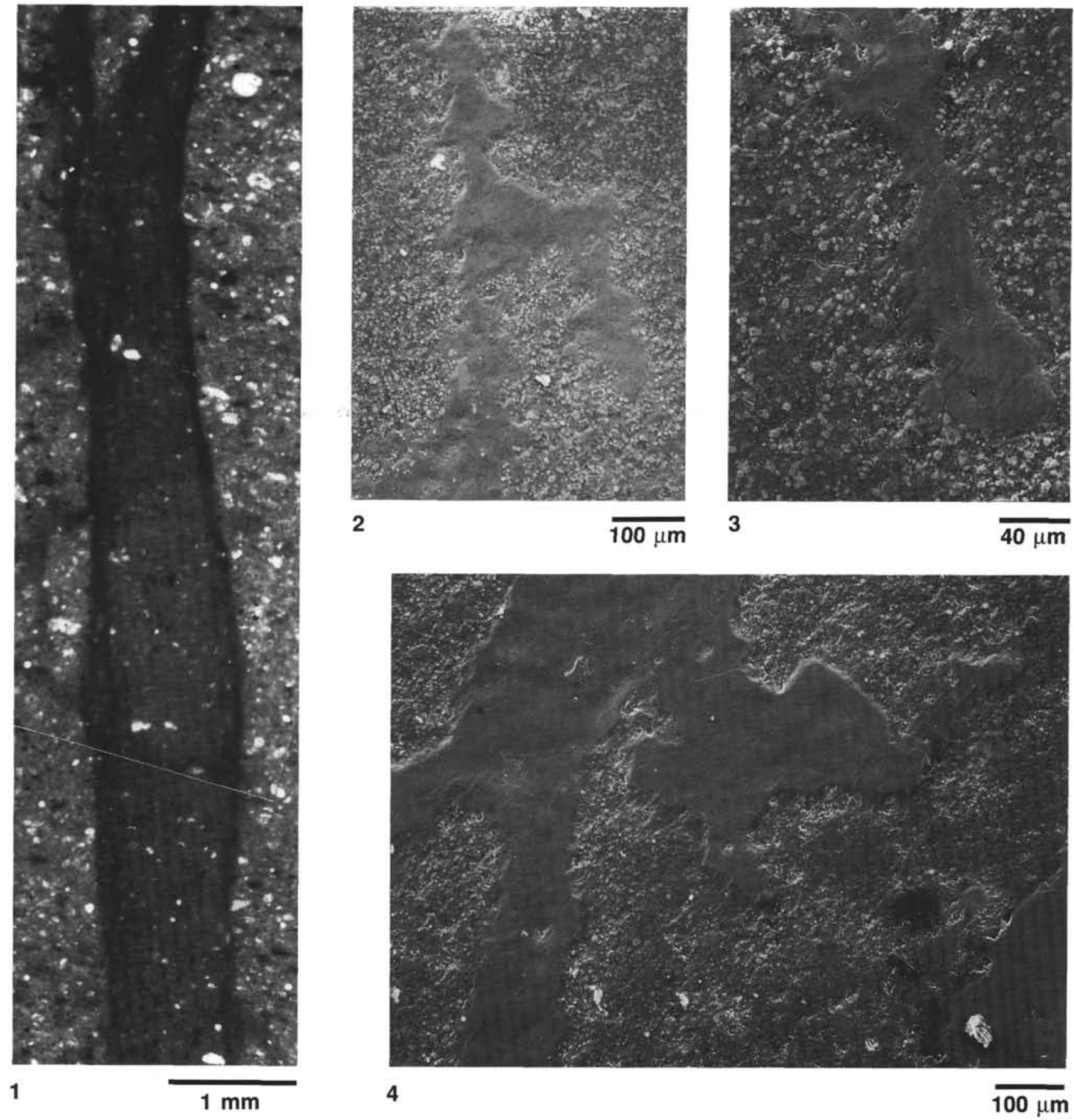

Plate 4. Dewatering veins. 1. Photomicrograph of a large vein showing the concentration of fines within it, especially at the margins, Section $128-799 \mathrm{~B}-15 \mathrm{R}-5$ at $56-69 \mathrm{~cm}$. 2-4. BSEI photographs of mud-filled extremities of a vein showing bifurcation (2 and 3) and even trifurcation (4); Sample 128-799B-26R-2, 50-52 cm. 


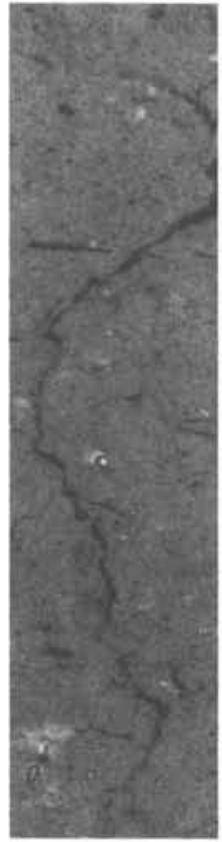

\section{1}

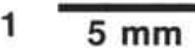

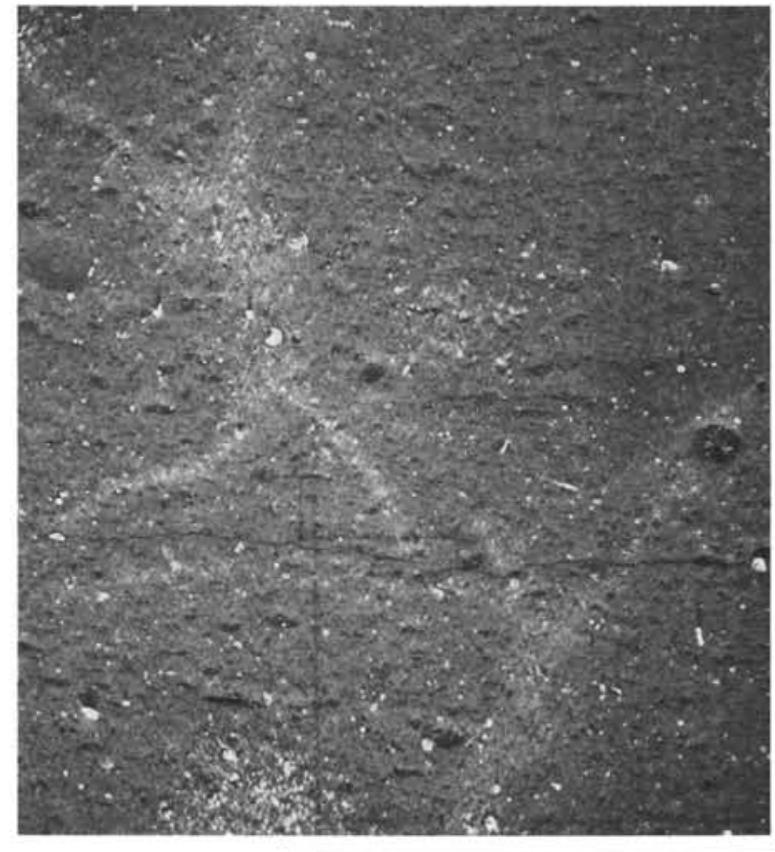

$1 \mathrm{~mm}$

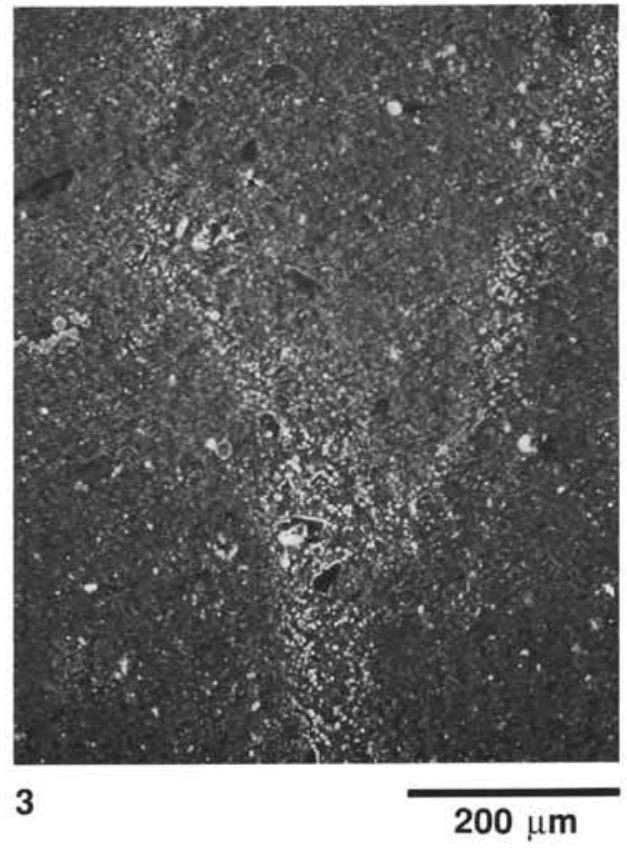

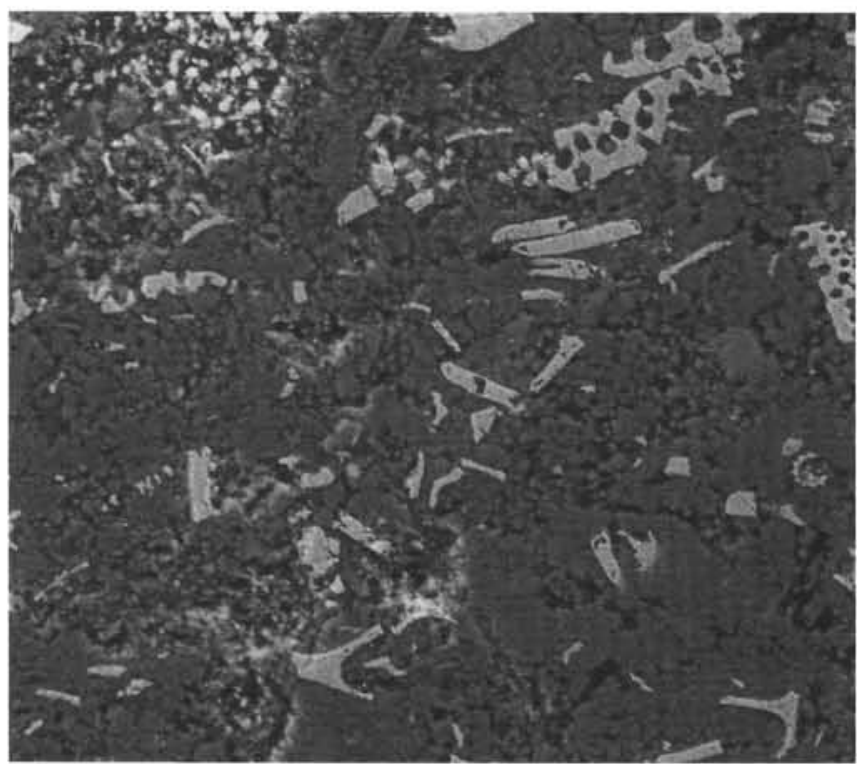

4
$10 \mu \mathrm{m}$

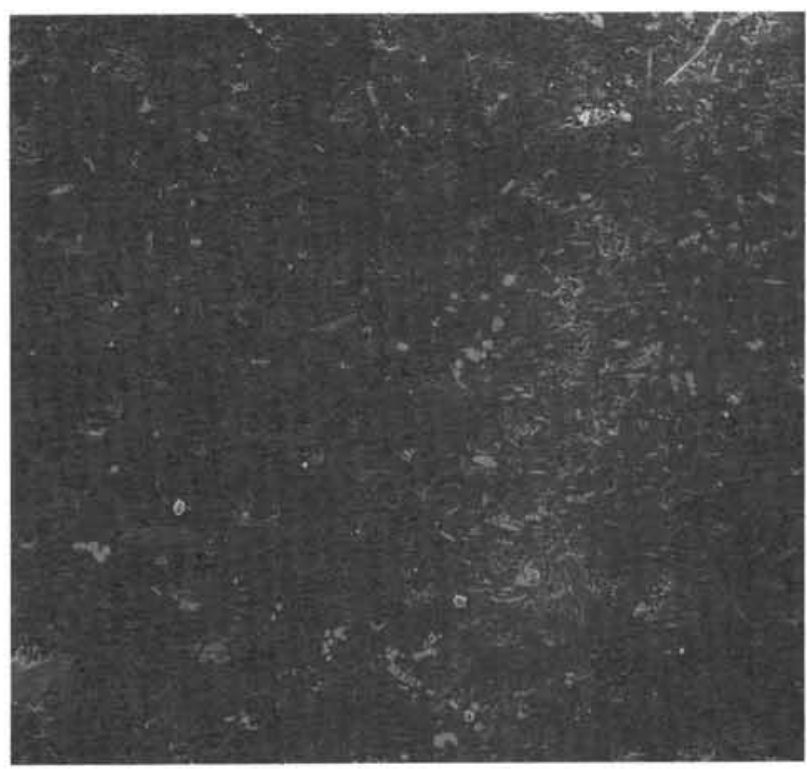

5

$65 \mu \mathrm{m}$

Plate 5. Dewatering veins. 1. Photomicrograph of a single sigmoidal vein; Sample 128-799B-21R-1, 104-107 cm. 2,3. SEM photographs of anastomosing veins; Samples 128-799B-26R-1, 146-148 cm (2), and 128-799B-23R-3, 5-10 cm (3). 4, 5. BSEI photographs of a vein showing concentration of coarse-grained diatom relicts and their slight orientation; Sample 128-799B-38R, 112-115 cm. 